University of Wollongong

Research Online

Faculty of Science - Papers (Archive)

Faculty of Science, Medicine and Health

January 2008

\title{
The nagssugtoqidian orogen in South-East Greenland: evidence for paleoproterozoic collision and plate assembly
}

\author{
Allen Phillip Nutman \\ University of Wollongong, anutman@uow.edu.au \\ Feiko Kalsbeek \\ Clark R L Friend
}

Follow this and additional works at: https://ro.uow.edu.au/scipapers

Part of the Life Sciences Commons, Physical Sciences and Mathematics Commons, and the Social and Behavioral Sciences Commons

\section{Recommended Citation}

Nutman, Allen Phillip; Kalsbeek, Feiko; and Friend, Clark R L: The nagssugtoqidian orogen in South-East Greenland: evidence for paleoproterozoic collision and plate assembly 2008, 529-572.

https://ro.uow.edu.au/scipapers/911

Research Online is the open access institutional repository for the University of Wollongong. For further information contact the UOW Library: research-pubs@uow.edu.au 


\title{
The nagssugtoqidian orogen in South-East Greenland: evidence for paleoproterozoic collision and plate assembly
}

\begin{abstract}
The $200 \mathrm{~km}$ wide, east-west trending Paleoproterozoic mobile belt of the Ammassalik region of SouthEast Greenland contains a diverse assemblage of Paleoproterozoic and Archean rocks, variably affected by Paleoproterozoic deformations and high-grade low or high pressure metamorphism. By using previous field and geochemical data combined with new zircon dating and zircon trace element geochemistry, this mobile belt is confirmed as a 1870 to $1840 \mathrm{Ma}$ collisional orogen, which contains one or more 1900 to 1880 Ma magmatic suites and northern and southern Archean basement terranes. The most studied 1900 to 1880 Ma magmatic suite is the Ammassalik Intrusive Complex, which is dominated by diorites (with arc-like geochemical signatures and with Paleoproterozoic Nd depleted mantle model ages), which was intruded into sedimentary rocks, (with predominantly Paleoproterozoic detrital zircons). Both these associated rock types show 1900 to 1880 Ma moderate pressure granulite facies metamorphism (7 kbar, $>=850$ degrees $\mathrm{C}$ ). Paleoproterozoic mylonites separate the Ammassalik Intrusive Complex from Archean orthogneisses containing $1870 \mathrm{Ma}$ eclogite (11 kbar, 650-700 degrees $\mathrm{C}$ ) and high-pressure granulite facies assemblages in Palaeoproterozoic diabase dike remnants. Associated with these Archean gneisses are pelitic metasediments, marbles and orthoquartzites (with Archean detrital zircon with complex 1870 to 1740 Ma metamorphic rims) that contain kyanite, thereby also showing high-pressure metamorphism. In the Ammassalik area we propose that one or more Paleoproterozoic magmatic arcs with syn-magmatic moderate pressure, high temperature metamorphism were emplaced over the edge of southern Archean continental crust. This resulted in at least doubling of crustal thickness, causing the transient $1870 \mathrm{Ma}$ eclogite to high-pressure granulite facies metamorphic conditions in the buried southern Archean terrane. Archean orthogneisses in the north of the mobile belt preserve low-pressure Archean granulite facies assemblages, and are interpreted as a different terrane at a higher structural level, which was juxtaposed with the southern eclogite-bearing Archean terrane and the lower pressure metamorphism Paleoproterozoic arc rocks during the collisional event(s). This new information from the Ammassalik region is used in a synthesis of Paleoproterozoic crustal accretion and collisional orogeny in Greenland.
\end{abstract}

\section{Keywords}

greenland, nagssugtoqidian, east, evidence, south, paleoproterozoic, orogen, collision, plate, assembly, GeoQUEST

\section{Disciplines}

Life Sciences | Physical Sciences and Mathematics | Social and Behavioral Sciences

\section{Publication Details}

Nutman, A. Phillip., Kalsbeek, F. \& Friend, C. R L. (2008). The nagssugtoqidian orogen in South-East Greenland: evidence for paleoproterozoic collision and plate assembly. American Journal of Science: An International Earth Science Journal, 308 (4), 529-572. 


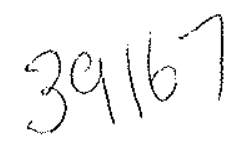

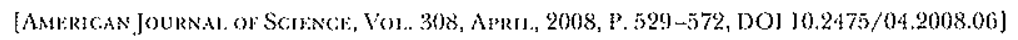

\title{
THE NAGSSUGTOQIDIAN OROGEN IN SOUTH-EAST GREENLAND: EVIDENCE FOR PALEOPROTEROZOIC COLLISION AND PLATE ASSEMBLY
}

\author{
ALLEN P. NUTMAN***, FEIKO KALSBEEK***;, and CLARK R. L. FRIEND $* \$$
}

ABSTRACT. The $200 \mathrm{~km}$ wide, east-west trending Paleoproterozoic mobile belt of the Ammassalik region of South-East Greenland contains a diverse assemblage of Paleoproterozoic and Archean rocks, variably affected by Paleoproterozoic deformations and high-grade low or high pressure metamorphism. By using previous field and geochemical data combined with new zircon dating and zircon trace element geochemistry, this mobile belt is confurmed as a 1870 to 1840 Ma collisional orogen, which contains one or more 1900 to 1880 Ma magmatic suites and northern and southern Archean basement terranes. The most studied 1900 to $1880 \mathrm{Ma}$ magmatic suite is the Ammassalik Intrusive Complex, which is dominated by diorites (with arc-like geochemical signatures and with Paleoproterozoic Nd depleted mantle model ages), which was intruded into sedimentary rocks, (with predominantly Paleoproterozoic detrital zircons). Both these associated rock types show 1900 to $1880 \mathrm{Ma}$ moderate pressure granulite facies metamorphism $\left(7 \mathrm{kbar}, \geq 850^{\circ} \mathrm{C}\right)$. Paleoproterozoic mylonites separate the Ammassalik Intrusive Complex from Archean orthogneisses containing 1870 Ma eclogite ( $\geq 11 \mathrm{kbar}, 650-700^{\circ} \mathrm{C}$ ) and high-pressure granulite facies assemblages in Palaeoproterozoic diabase dike remnants. Associated with these Archean gneisses are pelitic metasediments, marbles and orthoquartzites (with Archean detrital zircon with complex 1870 to $1740 \mathrm{Ma}$ metamorphic rims) that contain kyanite, thereby also showing high-pressure metamorphism. In the Ammassalik area we propose that one or more Paleoproterozoic magmatic arcs with syn-magmatic moderate pressure, high temperature metamorphism were emplaced over the edge of southern Archean continental crust. This resulted in at least doubling of crustal thickness, causing the transient $1870 \mathrm{Ma}$ eclogite to high-pressure granulite facies metamorphic conditions in the buried southern Archean terrane. Archean orthogneisses in the north of the mobile belt preserve low-pressure Archean granulite facies assemblages, and are interpreted as a different terrane at a higher structural level, which was juxtaposed with the southern eclogite-bearing Archean terrane and the lower pressure metamorphism Paleoproterozoic arc rocks during the collisional event(s). This new information from the Ammassalik region is used in a synthesis of Paleoproterozoic crustal accretion and collisional orogeny in Greenland.

\section{INTROBUCTION}

High-pressure granulite and eclogite assemblages are diagnostic of collisional orogenic events, because they form in deeply buried crust just after the tectonic thickening (for example, O'Brien and Rötzler, 2003). Because only fragments of ancient orogenic belts are preserved, their structure may no longer indicate clearly how they formed. However, these high-pressure metamorphic assemblages are a useful proxy for tectonic crustal thickening.

Near-isothermal decompression commonly follows the crustal thickening in a collisional event, when initially deeply buried rocks are rapidly exhumed as the crust is thinned by structural collapse, extension and erosion. Hence, the diagnostic metamorphic fingerprints of deeply buried crust in a collisional orogeny are formation of

*Beijing SHRIMP Center, Institute of Geology, Chinese Acadeny of Ceological Sciences, 26 Baiwanzhuang Road, Beijing 100037, China.

* Research Scliool of Eartl Sciences, Australian National University, Canberra, A.C.T. 0200, Australia

***Geological Survey of Demmark and Greenland, Geocenter Copenhagen, $\varnothing$ ster Voldgade 10, 1350 Copenhagen K, Demmark

$\$ 45$ Stanway Road, Headington, Oxford, OX3 OmP, United Kingdom 

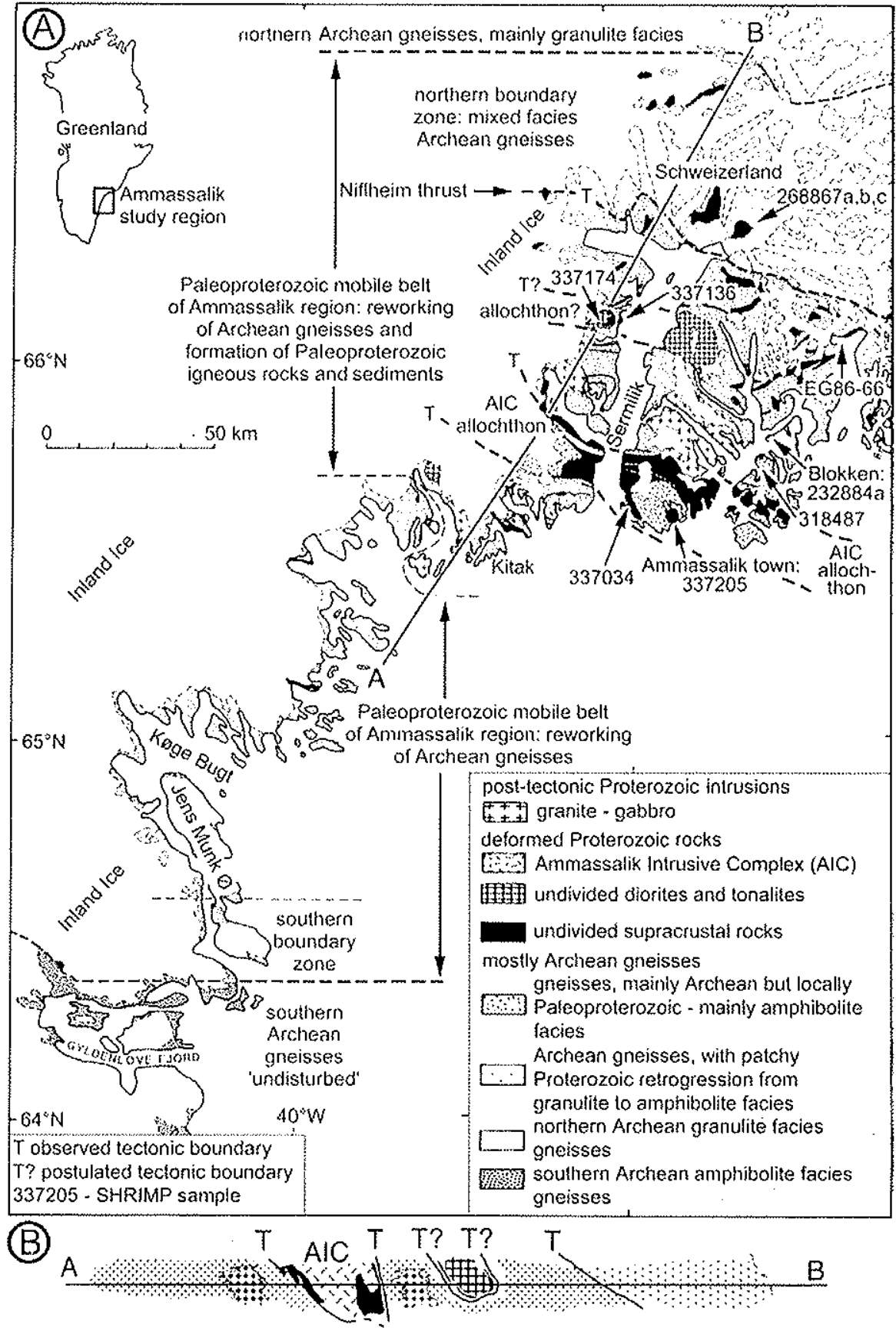

Fig. 1. (Top) Sketch geological map of the Ammassalik region, South-East Greenland. Shown are the sample locations and the main lithological divisions (after fig. 1 of Kalsbeek and others, 1989). Inset in the figure shows the location of the region in East Greenland. (Bottom) North to south section A-B across the region. This cross section synthesis shows interpretation as a collisional orogen. Features in this model agreeing with previous ones are: (1) Predominance of reworked Archean basement rocks, and (2) botl Archean and l'aleoproterozoic plutonic rocks are present. In previous models (for example, Nutman and Friend, 1989), the Paleoproterozoic intrusions were regarded as late in the tectonic evolution becaluse they did not show the high pressure metamorphlism. In this paper, they are re-interpreted as allochthononous 
high-pressure granulites \pm eclogites followed by recrystallization to lower pressure assemblages within a clockwise $P-T-t$ (pressure, temperature, time) path (for example, England and Thompson, 1984; O'Brien and Rötzler, 2003). Phanerozoic and Neoproterozoic collisional orogens yield increasingly reliable data on the high-temperature parts of P-T-t clockwise loops following initial crustal thickening by combining zircon in situ $\mathrm{U} / \mathrm{Pb}$ dating and rare earth element (REE) chemistry together with identifcation of the metamorphic parageneses to which the metamorphic zircons belong (for example, Hermann and others, 2001; Rubatto and Hermann, 2001). The European Alps are an example of this (for example, Rubatto and others, 1998; Rubatto and Scambelluri, 2003; Liati and others, 2005). Zircon is particularly useful in this methodology because of its common growth during highngrade metamorphism and its high effective blocking temperatures $\left(>900^{\circ} \mathrm{C}\right)$ for $\mathrm{U}$ and $\mathrm{Pb}$ diffusion (Lee and others, 1997). 'Therefore, providing that the zircon is not later recrystallized, it can retain its true age through superimposed tectonothermal events and hence preserve the age of its associated metamorphic paragenesis.

In Paleoproterozoic orogenic belts scattered relict eclogite facies metamorphic assemblages have been reported from pods of mafic rocks within reworked Archean basement gneisses. Examples are found in the Nagssugtoqidian orogen of East Greenland described in this paper, the Aldan Shield of eastern Siberia (Nutman and others, 1992; Smelov and Beryozkin, 1993) and the Lofoten islands of northern Norway (Markl and Bucher, 1997). Relict bigh-pressure granulite facies rocks are commoner within Paleoproterozoic orogenic belts, and are found in a similar setting as the eclogites, for example in the Trans North China orogen in the North China Craton (Zhao and others, 2000). These relict high-pressure metamorphic assemblages are indicative of collisional orogeny in the Palcoproterozoic. This evidence for collisional orogeny is strengthened further, when Paleoproterozoic orogenic belts with domains containing relict high-pressure metamorphic assemblages are juxtaposed with domains dominated by Paleoproterozoic igneous rocks that suffered only lowerpressure, high temperature granulite facies metamorphism. Such a situation is evocar tive of the paired metamorphic belts reported from Phanerozoic orogens (Miyashiro, 1973).

In this paper, the integrated metamorphic petrology - zircon geochronology and geochemistry approach developed in Phanerozoic-Neoproterozoic collisional orogens is used for further study of the Nagssugtoqidian orogenic belt in East Greenland. In 1986, this belt was the focus of a major field study and mapping program by the Geological Survey of Greenland (Kalsbeek and Nielsen, 1987; Kalsbeek, 1989; Escher; 1990). At that time the term 'Ammassalik mobile belt' was used for this region because correlation with the Nagssugtoqidian orogen of West Greenland (fig. 1 inset) was not well established. Since then airborne aeromagnetic studies have demonstrated a probable continuity of the Nagssugtoqidian orogenic belt from West Greenland underneath the Inland Ice to the Ammassalik region (Verhoef and others, 1996; van Gool and others, 2002), and the term Ammassalik mobile belt can therefore be abandoned.

Using the modem zircon dating and chemistry techniques, together with insight gained into Paleoproterozoic orogeny from other belts over the past two decades (particularly the western segment of the Nagssugtoqidian belt - Kalsbeek and Nutman,

bodies in upper thrust slab(s), and hence did not experience high pressure metamorphism. This interpretation requires that the Nagssugtoqidian in East Greenland is a collisional orogen with one or more sutures that separate the structurally decp domains with high pressure metamorphism, from structurally high domains devoid of that metamonphism. Sample numbers refer to the files of the Geological Survey of Demmark and Grecmland. 
1996; Nutman and others, 1999; van Gool and others, 2002), this paper explores the case that the Nagssugtoqidian belt in East Grecnland formed by collisional orogeny. In this orogeny, unrelated northern and southern blocks of Archean basement, diverse packages of Paleoproterozoic sediments and Paleoproterozoic igneous (arc) complexes were tectonically juxtaposed and deformed together. The present paper builds upon the earlier work under the auspices of the Geological Survey of Greenland and Denmark (Kalsbeek, 1989) and the radiogenic isotopic results and age determinations presented by Kalsbeek and others (1993). However, new zircon geochronology and geochemistry presented here has led to significant revision of some earlier interpretations (see for example the metamorphic history presented by Nutman and Friend, 1989 compared with the interpretation in this paper).

\section{GEOLOCYY OL THE AMMASSALIK RECION}

Most of the Precambrian terrain in South-East Greenland consists of polyphase Archean orthogneisses. In the Ammassalik area (fig. 1), these have been reworked in the Paleoproterozoic Nagssugtoqidian orogenic belt. This belt also contains major units of younger tonalitic rocks, high-grade metasedimentary rocks, suites of metadiabase dikes, a complex of dioritic, noritic and granitic rocks (the Ammassalik Intrusive Complex), and post-tectonic granite intrusions. Earlier work in the region is summarized in Kalsbeek (1989) and Kalsbeek and others (1993). An outstanding finding from early studies was the recognition of relict, largely decompressed eclogite facies assemblages within metadiabase dike relicts (Wright and others, 1973). As elaborated upon below, the relationship and timing of metamorphism between rocks that suffered high-pressure metamorphism and nearby ones that suffered only moderate-pressure metamorphism is a key to understanding the Nagssugtoqidian belt in the Ammassalik region.

The geology of the Ammassalik region is very complex, but well exposed in a rugged Arctic terrain (fig. 2). Detailed mapping is restricted to small selected areas mainly because large parts of the region are difficult to access even by helicopter (fig. 2). The last and most complete survey of the geology of the Ammassalik region has been presented in the Geological Survey of Greenland's volume "Geology of the Ammassalik region, South East Greenland" (Kalsbeek, 1989). This followed on from earlier less complete coverages of the region (for example Wright and others, 1973; Myers, 1987).

The main rock units of the Ammassalik region (fig. 1) are as follows:

(1) Polyphase tonalitic to granodioritic orthogneisses with complex deformation histories form large parts of the region (figs. 2A and 2B). Most of these are of Neoarchean age (Kalsbeek and others, 1993 and references therein). Before the regional mapping of the Ammassalik region by the Geological Survey of Greenland in 1986, an area of Archean gneisses northeast of Ammassalik had been tentatively mapped as a separate unit of (possibly early Paleoproterozoic) dionitic to tonalitic intrusive rocks, and were labeled as the 'Blokken gneisses' (for example, Bridgwater and Myers, 1979). However, field observations by Dawes and others (1989a) did not confirm any differences with the surrounding Archean gneisses, and preliminary dating of samples from Blokken gneisses suggested ages around $3000 \mathrm{Ma}$ (Kalsbeek and others, 1993).

Some other gneisses have yielded Paleoproterozoic bulk zircon U-Pb zircon dates and Sm-Nd model ages ( $\mathrm{T}_{1 \mathrm{M}}$ ), indicating they are not Archean (Kalsbeek and others, 1993). These younger rocks form a significant body in the northern part of the Ammassalik region on either side of Sermilik (fig. 1) and comprise dioritic to tonalitic orthogneisses with accessory garnet in some instances. These tend to be more homogeneous than most Archean gneisses and, compared to the latter, metadiabase dikes are rare. In the 1986 mapping; no sharp boundaries were observed between these 
rocks and the surrounding Archean gneisses. Nearby Archean orthogneisses just south of this body contain relict eclogite pods (Nttman and Friend, 1989).

In the northernmost part of the orogen the regional gneisses are Archean granulites (Dawes and others, 1989b; Kalsbeek and others, 1993); the 'northern Archean gneiss' on figure 1. There is no thermobarometric data on these granulite facies rocks. However they bear most commonly orthopyroxene with only infrequent garnet, suggesting low- to medium-pressure metamorphism. Towards the south in the area 'Schweizerland' on figure 1, these are progressively retrograded to (hornblende-) biotite gneisses. On the outcrop scale retrogression can appear static (fig. $2 \mathrm{C}$ ), on the regional scale it is probably related to major Paleoproterozoic tectonism farther south in the region. The Nifhem thrust (Escher and Hall, 1989; fig. 1) divides a northern hanging wall, within which no Paleoproterozoic granitoid rocks have been recognized, from a more complex footwall domain to the south consisting of Archean and Paleoproterozoic rocks, all deformed and metamorphosed in the Paleoproterozoic.

(2) Supracrustal rocks, locally at granulite facies, are another prominent lithological component. These are predominantly metapelites, marbles and quartaites, wilh lesser amounts of amphibolite (Chadwick and others, 1989; Hall and others, 1989). These form units that can be more than a kilometer thick, and occur complexly interfolded with the orthogneisses (Chadwick and Vasudev, 1989). Kyanite is quite common in these rocks, indicating that some underwent high-pressure metamorphism. Field observations have rarely provided unequivocal evidence for the age relationship between the supracrustal gneisses and the surrounding orthogneisses. Contacts are nearly always tectonic, although at a few localities components of the gneisses have been observed to penetrate supracrustal units (Chadwick and others, 1989). Isotopic evidence (Kalsbeek and Taylor, 1989; Kalsbeek and others, 1993) indicates Paleoproterozoic ages for several of the supracrustal units; however it is not certain whether they all have the same age and origin.

(3) The Ammassalik Intrusive Complex (AIC of Friend and Nutman, 1989) occurs in the center of the region, around Ammassalik town. It consists of commonly undeformed (moderate pressure) hypersthene-granulite to amphibolite facies granitic, intermediate and basic rocks (norites and hypersthene diorites). The Ammassalik Intrusive Complex was emplaced into a package of supracrustal rocks dominated by sedimentary protoliths, within which it caused widespread anatexis. The resulting migmatitic rocks are commonly rich in garnet, and can carry hypersthene and sillimanite, rather than kyanite. Clinopyroxene-orthopyroxene thermometry on a diorite (sample GGU-318308) yielded 830 to $850^{\circ} \mathrm{C}$, and a pressure of $7.5 \mathrm{kbar}$ by clinopyroxenewplagioclase barometry at those temperatures (Nutman and Friend, 1989). Mingling of granitic neosome derived from the sediments and dioritic and noritic rocks is widespread in the complex. No detailed geochemical data are available for the Ammassalik Intrusive Complex, but coeval and lithological similar dioritic rocks in the Nagssugtoqidian belt of West Greenland have chemical affinities with arc andesites (Kalsbeek and others, 1987; Kalsbeek, 2001), and we suggest that the AIC also forms part of a Paleoproterozoic arc. This is supported by major element analyses of the diorites indicating that they have compositional affinities with arc andesites (Friend, unpublished whole rock analyses). They show close to slightly sub-chondritic initial $\varepsilon_{\text {Nd }}$ values (Kalsbeek and others, 1993), indicating contributions of both Archear and juvenile Paleoproterozoic material. Hansen and Kalsbeek (1989) obtained an isotope dilution themal ionization mass spectrometry (IDTIMS) age of $1886 \pm 2 \mathrm{Ma}$ for an undeformed diorite in the Complex, using bulk zircon fractions of different size and magnetic susceptibility. The age and metamorphic history of the Ammassalik Intrusive Complex is addressed here by further zircon studies. North and south of the Ammassalik Intrusive Complex, its carapace of metasedimentary rocks 


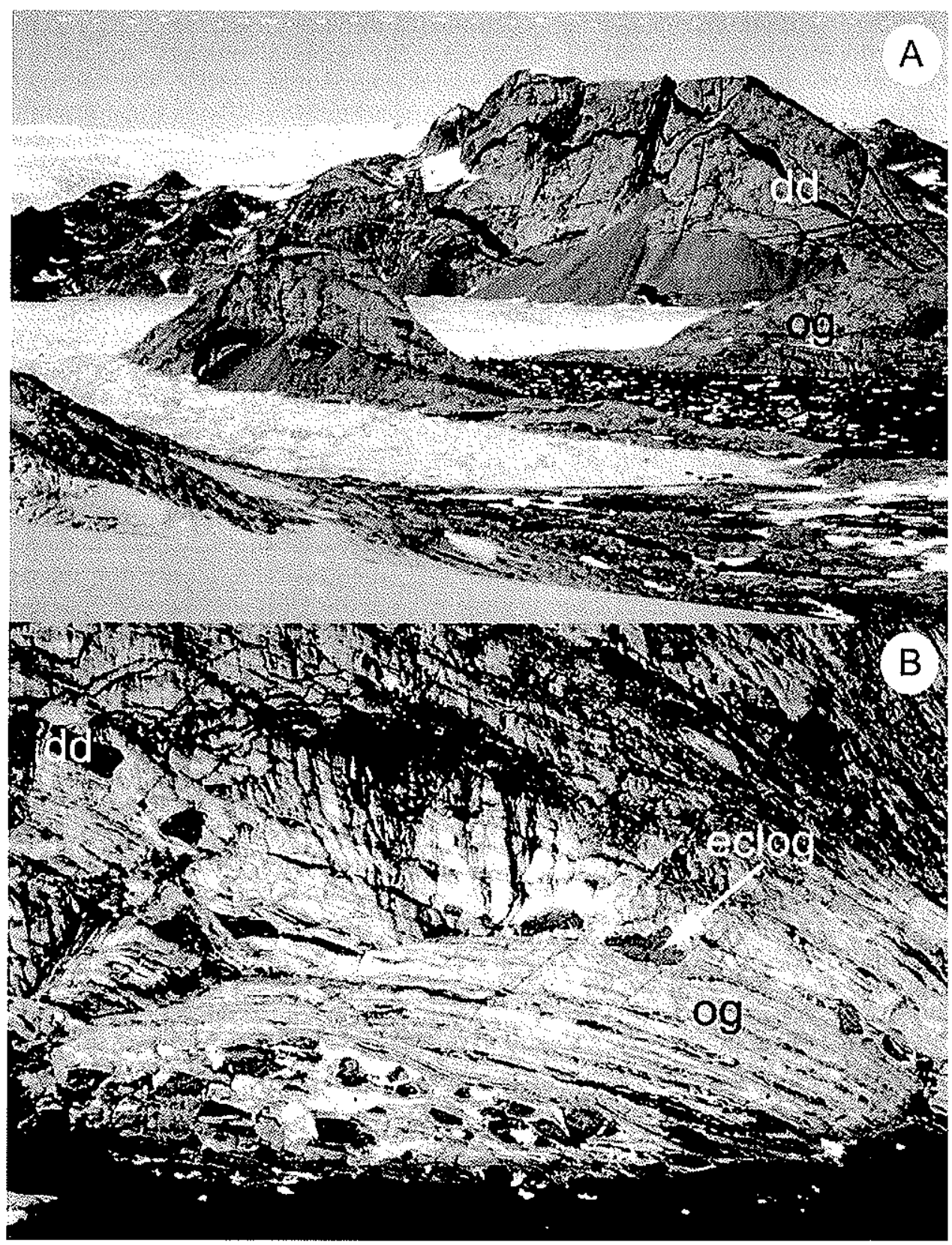

Fig. 2. Geological relationships in the Ammassalik region. (A) Southern foreland of Archean or thogneisses $(0 \mathrm{~g}$ cut by undeformed but slighnly recrystallized Paleoproterozoic metadiabase dikes (dd) from are" shown as 'southem Archean gneisses, undisturbed' in the southern part of figure 1. Height of mountains circa $800 \mathrm{~m}$. (B) Reworked basement orthogneisses $(\mathrm{og})$ in the central part of the orogen, north of the proposed AIC alloclathon. The Paleoproterozoic metadiabase dikes (dd) have been converted into tabular bodies of amphibolite, whose margins are concordant with the pegmatite banding in the originally host orthogneisses. Within the centers of larger dike pods there are preserved patches with eclogite facies assemblages (eclog). Ductile defommation is considerable. North of Ammassalik Intrusive Complex. Height of section is circa $200 \mathrm{~m}$. 

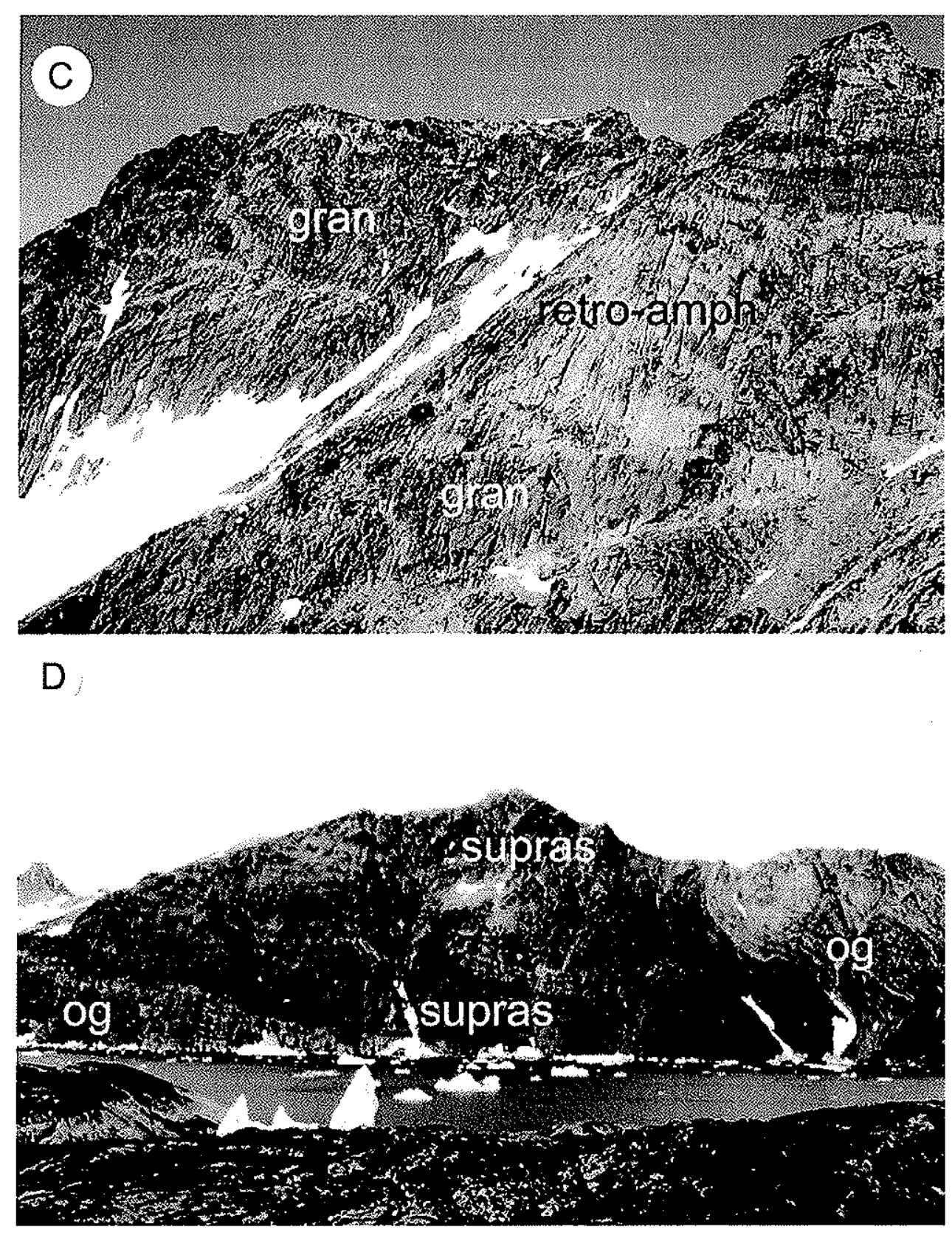

Fig. 2 (continued). Geological relationshipss in the Ammassalik region. (C) Northern Archean gneisses showing domains of relice Archean granulite facies assemblages (gran) being retrogressed under amphibolite facies conditions (retro-amph), from the 'Schweizerland' area in figure 1. Photograph courtesy of P. R. Dawes. (D) View morthwards across Bjomebugt in the northern part of the orogen, near the EG86-66 locality on figure 1 . Gray regional orthogneisses (og) are in a recumbent fold with a supracrustal unit (supras) consisting of amphibolites and paragneisses. Bonndaries between these important lithological units are concordant and sheared, which makes it impossible in the field to defineate the original relationships. 
shows decreasing amounts of in situ anatexis with orthopyroxene + sillimanite as restite phases. Plagioclase sillimanite thermobarometry on an anatectic metasediment (sample GGU-316254) yielded temperatures of 770 to $820^{\circ} \mathrm{C}$ at $7.5 \mathrm{kbar}$ (Nutman and Friend, 1989). The age of detrital zircon provenance and timing of high-grade metamorphism (s) are addressed here by new zircon dating.

The contact of these rocks with the Archean orthogneisses to the north (that contain pods of relict eclogite and high-pressure granulite) is a steeply dipping amphibolite facies mylonite (fig. 1), cut by post- kinematic late Paleoproterozoic granites (Friend and Nutman, 1989; Kalsbeek and others, 1993). The contact with Archean gneisses to the south with pods of relict high pressure granulite is sharp and isoclinally folded (fig. 1 of Friend and Nutman, 1989), and we contend in this paper that it is likely to be a mylonite that was subsequently folded and metamorphosed.

(4) Metadiabase dikes constitute a minor, but persistent lithological component of the Ammassalik region (Wright and others, 1973; Bridgwater and Myers, 1979). Sm-Nd whole rock dating of a composite dike from Bjørnebugt in the north of orogen yielded an errorchron $(M S W D=5.50)$ with an apparent age of $2170 \pm 190 \mathrm{Ma}$, suggestive of a Paleoproterozoic age (Kalsbeek and others, 1993). The dikes are abundant in the orthogneisses, and rare to absent in the metasediments, the Ammassalik Intrusive Complex and other orthogneiss bodies of likely Paleoproterozoic age. They have undergone variable amounts of Paleoproterozoic deformation and metasomatism. In the south, in the area 'southern Archean gneisses, undisturbed' in figure 1, the dikes are strongly discordant to fabrics and structures in their host Archean rocks, and occur as parallel-sided tabular bodies (fig. 2A). They show weak, lowest amphibolite to greenschist facies recrystallization, and relict igneous minerals are preserved (Escher and others, 1989). Northwards, there is progressive deformation, first discrete Paleoproterozoic shear zones, and then distributed ductile deformation (Escher and others, 1989). The orthogneisses here generally display amphibolite facies assemblages, and the dikes are generally preserved as trains of amphibolite pods (plagioclase +hornblende \pm garnet), with only rare preservation of the original discordant contacts. In the northern and central parts of the orogen (north of Kitak on fig. 1), large pods of amphibolite derived from the dikes can contain relicts of eclogite and high pressure granulite assemblages (fig. 2B; Wright and others, 1973). Pressures of up to $11 \mathrm{kbar}$ have been recorded from the decompressed assemblages (Nutman and Friend, 1989; Mengel and others, 1990). In all cases, eclogitic clinopyroxene has exsolved sodic plagioclase (fig. 3). Reconstruction of clinopyroxene compositions indicates it originally carried $11 \mathrm{wt} \% \mathrm{Al}_{2} \mathrm{O}_{3}$ and $6.5 \mathrm{wt} \% \mathrm{Na}_{2} \mathrm{O}$ (Nutman and Friend, 1989). These assemblages are invariably small remnants of more extensive domains throughout the dikes that have been widely recrystallized and hydrated under lower pressure conditions. Thus not only is the clinopyroxene full of exsolved lamellae of albite, but garnet can show early breakdown symplectites of plagioclase + orthopyroxene prior to more widespread growth of hornblende + plagioclase at the expense of clinopyroxene and garnet (figs. 2 and 3 of Nutman and Friend, 1989).

A previous Sm-Nd study of eclogite clinopyroxene (with exsolved albite lamellae), gamet and whole rock yielded an isochron (MSWD $=0.28$ ) with an age of $1817 \pm 22$ Ma (Kalsbeek and others, 1993). This result is here integrated with U/Pb geochronology and REE chemistry of zircons from these dikes to provide a more precise intrusive age for some of these dikes and more detail on their metamorphic history. Dikes with high-pressure metamorphic relicts have been found as far north as within $1 \mathrm{~km}$ from the Nifheim thrust (Escher and Hall, 1989). Other dikes have been reported north of the orogen, but relict high-pressure patches have not been seen in them. Where these dikes cut granulite facies gneisses, they are generally weakly deformed to undeformed (Dawes and others, 1989b). 


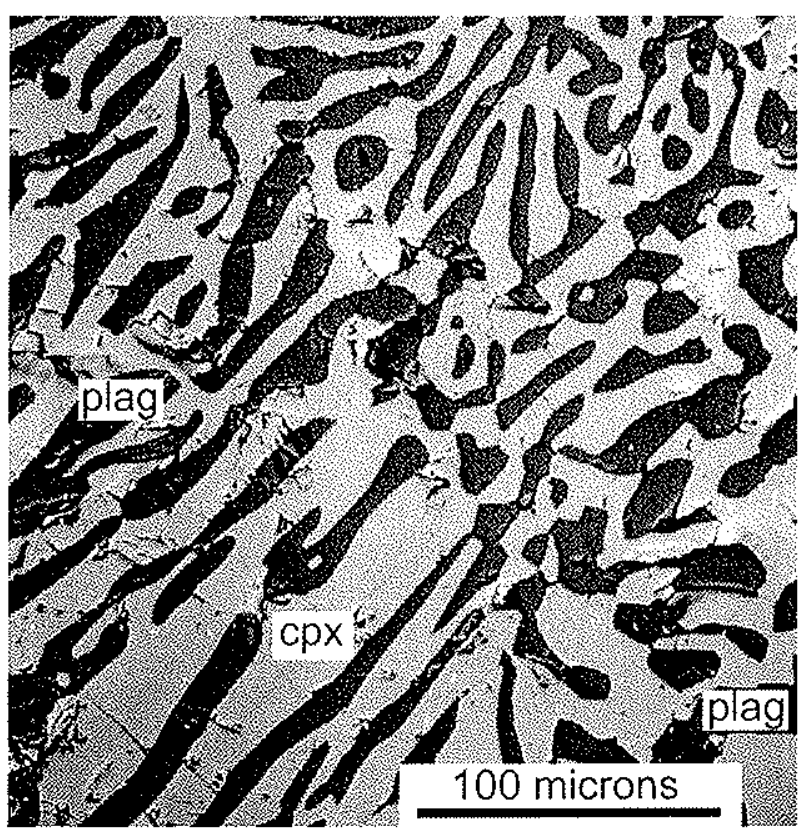

Fig. 3. Back Scattered Electron image of albite-rich plagioclase exsolution out of clinopyroxene in relict eclogite sample GGU-313153.

(5) The youngest Precambrian rocks of the region are a posi-tectonic suite of granites, diorites, and local gabbros. These have sharp intrusive contacts, and narrow contact aureoles whose mineralogy suggests emplacement at moderate to low pressures (sample GGU-3182356, circa $2.5 \mathrm{~kb}$; Nutman and Friend, 1989). Bulk zircon IDTIMS dating of these granites provided ages of circa $1680 \mathrm{Ma}$ (Kalsbeek and others, 1993). This shows that when these granites were emplaced, approximately 200 million years after the main orogenic events, that exhumation was almost complete.

The structural and metamorphic evolution of the Ammassalik region is complex, even in the rocks agreed to be Paleoproterozoic in age. Early tectonic contacts between for example Paleoproterozoic metasedimentary rocks and Archean orthogneisses are overprinted by at least two episodes of nonwcylindrical folding with early recumbent isoclines, followed by folds with steeply inclined northwest-trending axial surfaces. Tectonic contacts also display complex histories, which may involve both early interleaving along thrusts, and episodes of later extension. Accordingly, the common concordant, strongly deformed contacts between units are hard to decipher (fig. 2D). These problems of interpretation arise from the still incomplete structural coverage of the region, where many superb structural relationships in the alpine terrain only seen by helicopter fly-by (because it is impossible to land) or during brief reconnaissance stops (for example, Myers, 1987; Chadwick and Vasudev, 1989; Chadwick and others, 1989). The previous reports described interleaving of unrelated lithological units and recumbent folding in a regime of north-south compression (for example, Chadwick and others, 1989), and it was noted that vestiges of high-pressure assemblages such as eclogite patches in metadiabase dikes and kyanite within metasediments were early in the tectonothermal development. Both these are consistent with a clockwise P-T loop due to tectonic crustal thickening and collapse (for example, Nutman and Friend, 1989). Although it was realized at that time that many aspects of the geology of the 
Nagssugtogidian of East Greenland are compatible with a collisional setting (for example, Kalsbeek and Taylor, 1989), none of the previous studies succeeded in identifying a suture within the mobile belt and to provide conclusive evidence that it is indeed a collisional orogen produced under a plate tectonic regime.

ZMRCON SHRIMP U/PD GLOCHRONOLOGY AND LA-ICP-MS TRACE WILMINT GHOCHIMISTRY

Data Acquisition and Interypetation

Zircons from nine samples were dated by the SHRIMP U/Pb zircon method, using the SHRIMP 1 and SHRIMP RG instruments at the Research School of Earth Sciences, Australian National University and the SHRIMP 2 instrument at the Chinese Academy of Geological Sciences (table 1). ${ }^{238} \mathrm{U} /{ }^{206} \mathrm{~Pb}$ in the unknowns was referenced to QGNG or FCl zircons with ages of 1850 and $1099 \mathrm{Ma}$ respectively, and $U$ was calibrated against fragments of the $238 \mathrm{ppm}$ U zircon SL13. Samples GGU-268867, GGU-232884, GGU-337136, GGU-337174 and EG86-66 were analyzed in the mid 1990s, prior to CL. imaging being used routinely to document the interior structure of the zircons. Postanalysis CL imaging was undertaken on these in the 2000s, with additional CL-guided analyses undertaken in some samples. In addition, entirely CL-guided analyses were then undertaken on GGU-318487, GGU-337205 and GGU-337034. Analytical protocols, calibration of data and calculation of analytical errors are summarized by Stern (1998) and Williams (1998). Data assessment via Terra Wasserburg ${ }^{238} \mathrm{U} /{ }^{206} \mathrm{~Pb}$ versus ${ }^{207} \mathrm{~Pb} /{ }^{206} \mathrm{~Pb}$ concordia plots, cumulative probability figures, weighted mean dates (reported in the text with $95 \%$ confidence limits) and multiple age components were calculated using the unmix routine of the Program ISOPLOT3.xla (Ludwig, 2003).

In situ trace element abundances in zircon (table 2) were obtained at RSES, ANU, using a Lambda Physik LPX 1201 UV ArF excimer laser instrument coupled to an Aligent 7500 inductively coupled plasma mass spectrometer (LA-ICP-MS). Sites for laser ablation analyses were chosen using the CL images as a guide and many were started over c. $1 \mu \mathrm{m}$ deep SHRIMP U/Pb dating analytical pits. Data were assessed by plotting them as chondrite-normalized REE pattern diagrams. The zircons mounted in epoxy resin were placed in an Ar.He flushed sample cell (Eggins and others, 1998). The laser was operated at constant voltage, $21-23 \mathrm{kV}$ at $5 \mathrm{~Hz}$, with a spot diameter of 29 to $50 \mu \mathrm{m}$. Ablated material was carried by the He-Ar gas via a custom-made flow homogeniser to the ICP-MS. Data were acquired for c. $20 \mathrm{~s}$ with the laser beam turned off (for backgrounds) and c. $40 \mathrm{~s}$ with the laser on. This acquisition mode gives approximately 120 mass scans with a penetration depth of $20 \mu \mathrm{m}$. Each block of four unknowns was bracketed by analyses of glass reference material NIST610. Raw count rates were converted offline into concentrations using an Excel ${ }^{\text {rM }}$ spreadsheet algorithm (written by S. Eggins and C. Allen, ANU). Corrections for mass bias drift in unknowns were made using the bracketing NIST610 glass analyses (Norman and others, 1996). Trace element abundances were normalized assuming $\mathrm{Zr}_{2} \mathrm{O}=64 \mathrm{wt} \%$ in the zircons (appropriate for a typical zircon with a few percent Hafnon solid solution).

\section{Northern Archean Orthogneisses}

Three samples of orthogneiss collected by the late David Bridgwater and others during the late 1970s helicopter reconnaissance mapping are representative of the variably retrogressed northern granulite facies gneisses (see fig. 1). The samples (GGU-268867a,b,c) are from a locality in the mountainous region Charcot Fjelde at approximately $66^{\circ} 24^{\prime} \mathrm{N} 36^{\circ} 59^{\prime} \mathrm{W}$. Previous TIMS U-Pb zircon data (on different size and magnetic fractions from all three samples) have yielded an upper intercept age of $2835^{+6 / 8}$ Ma (Kalsbeek and others, 1993). 


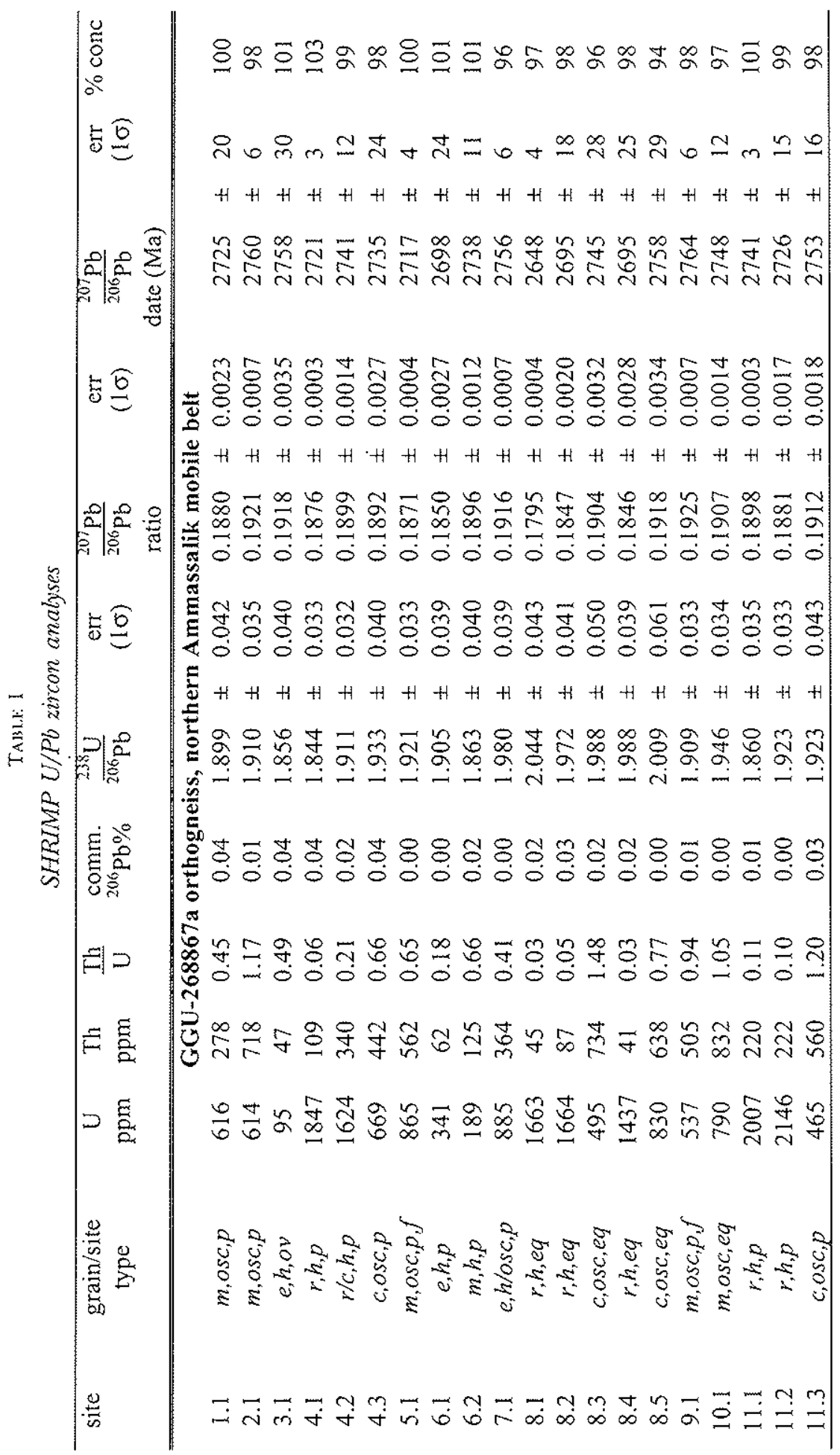




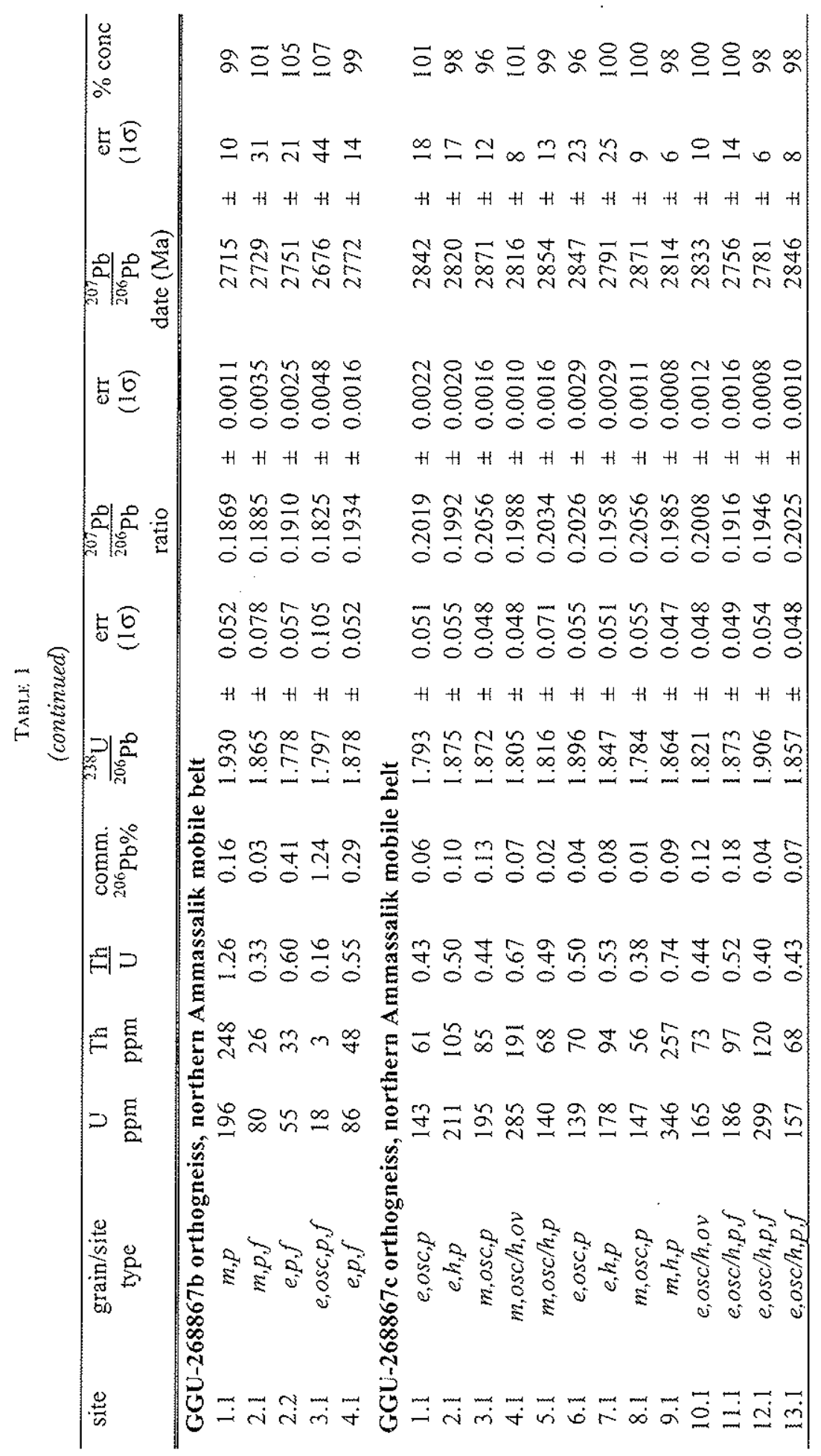




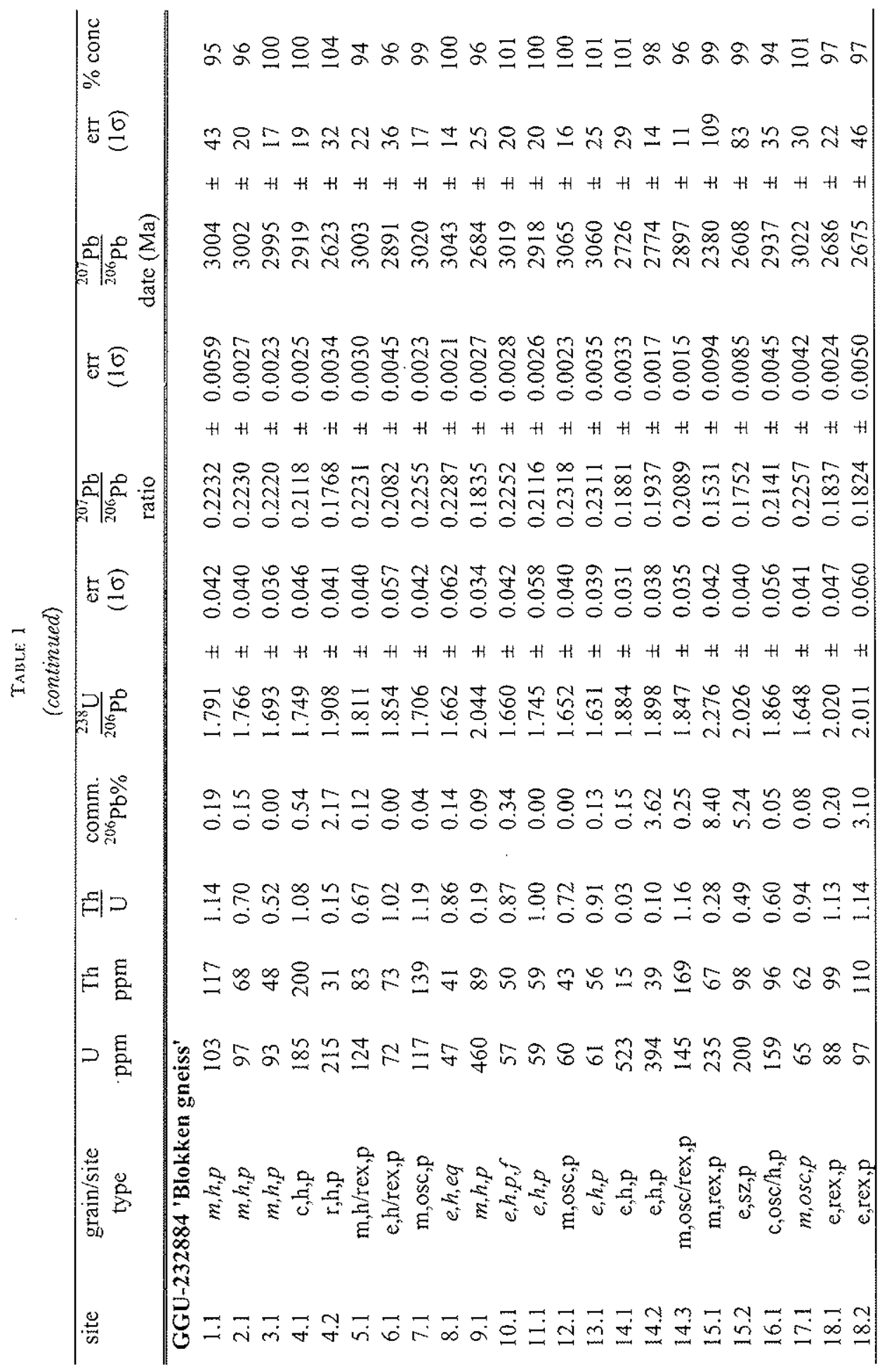




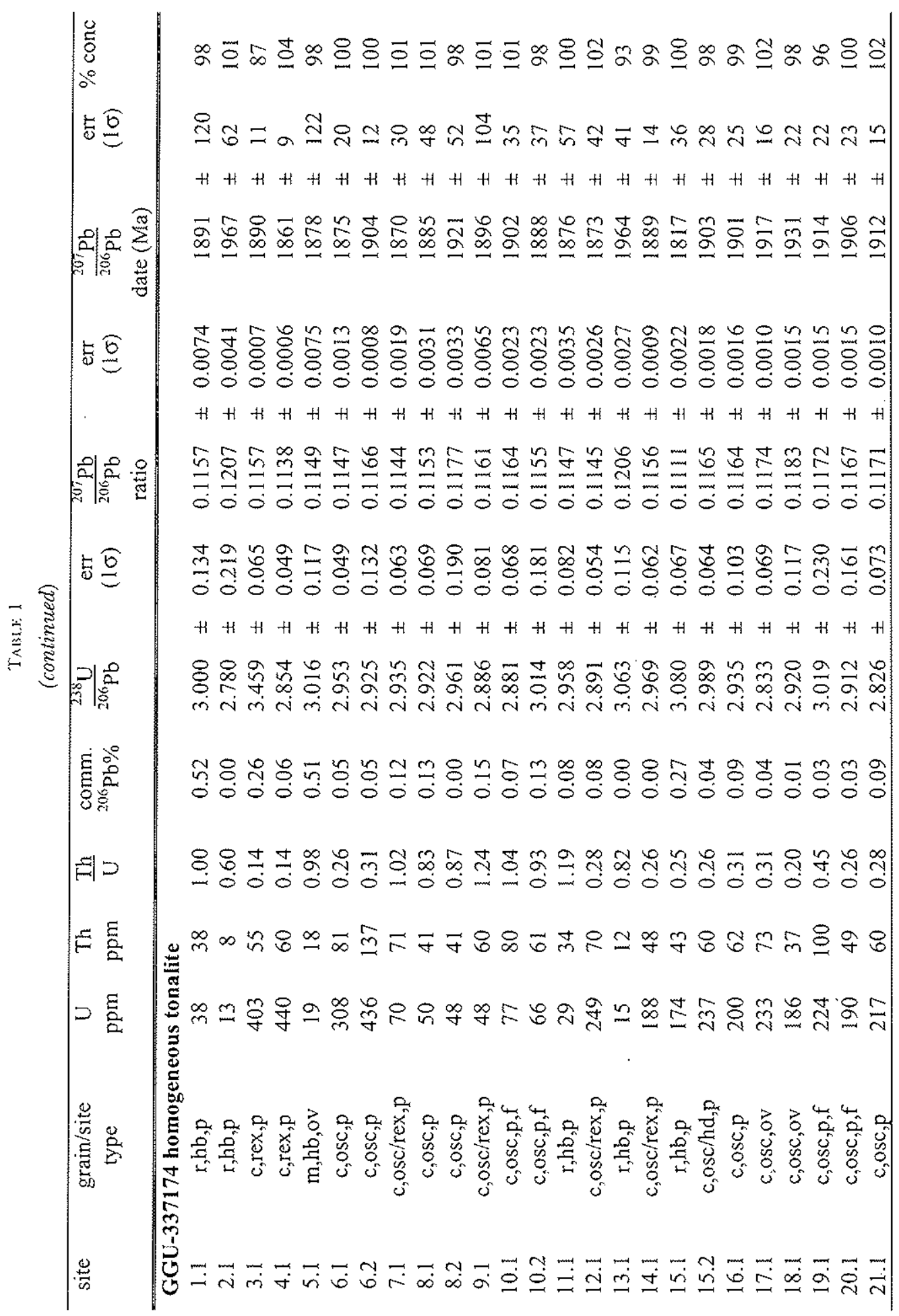




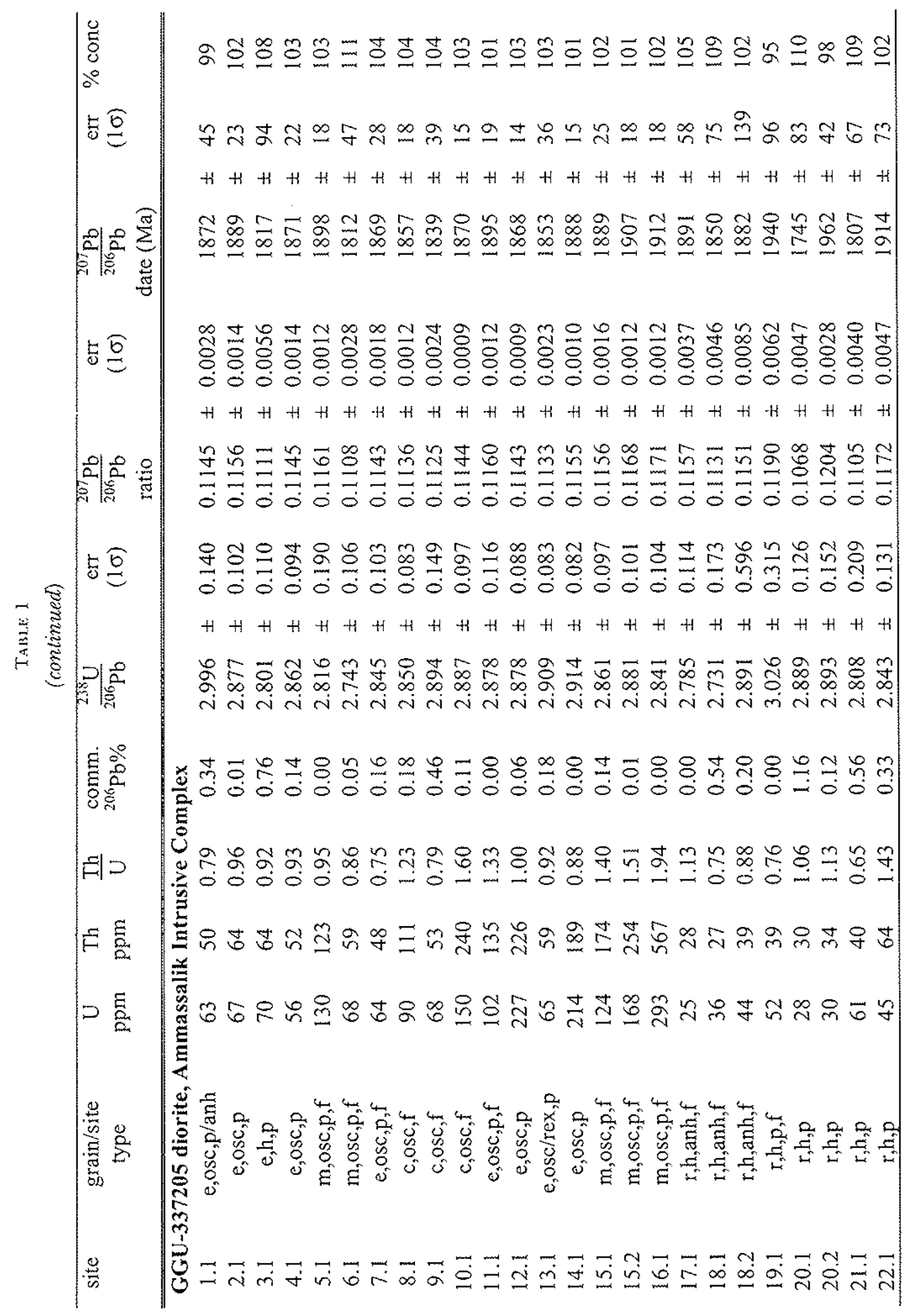


544 A. P. Nutman and others-The Nagssugtoqidian Orogen in South-East Greenland:

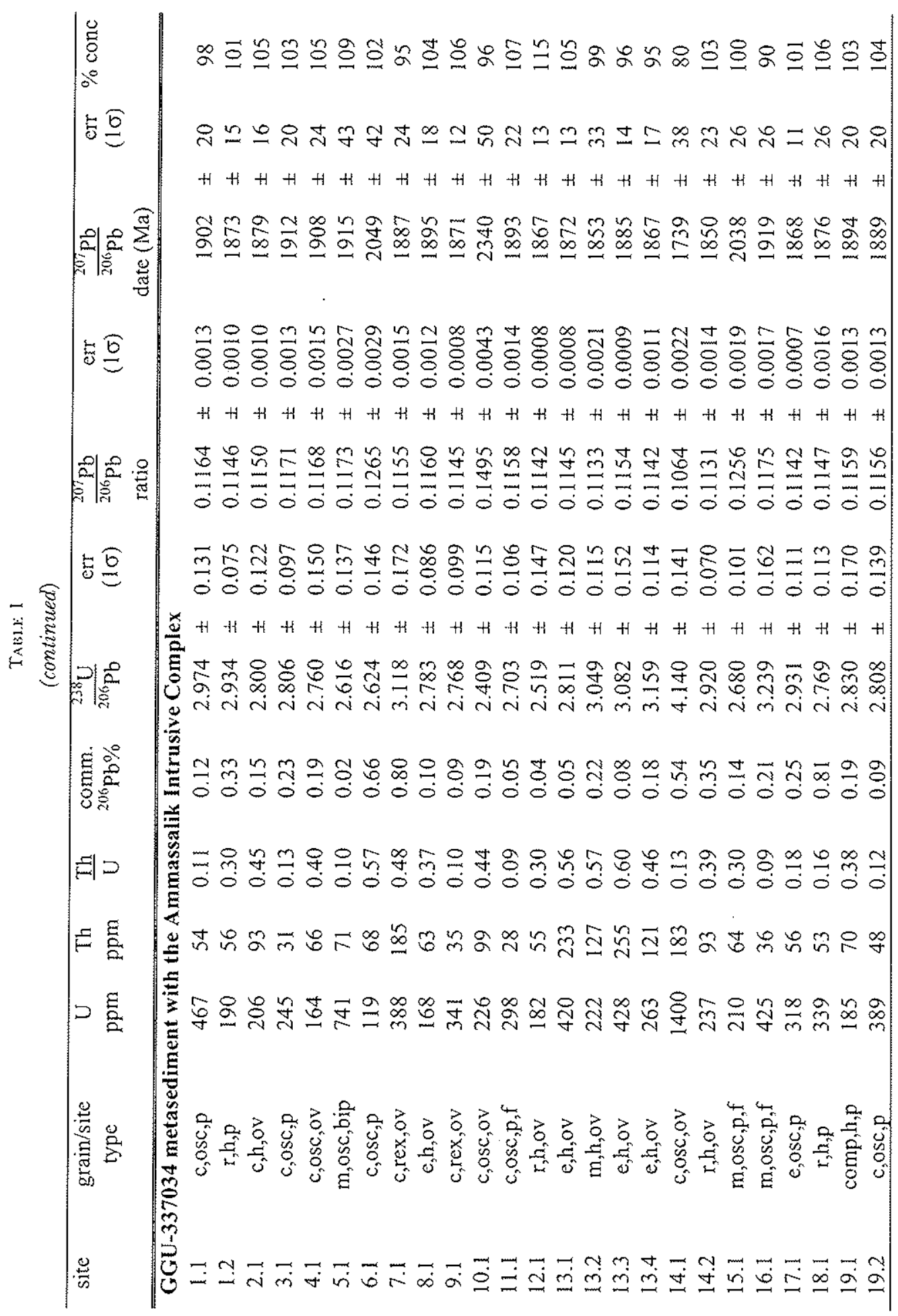




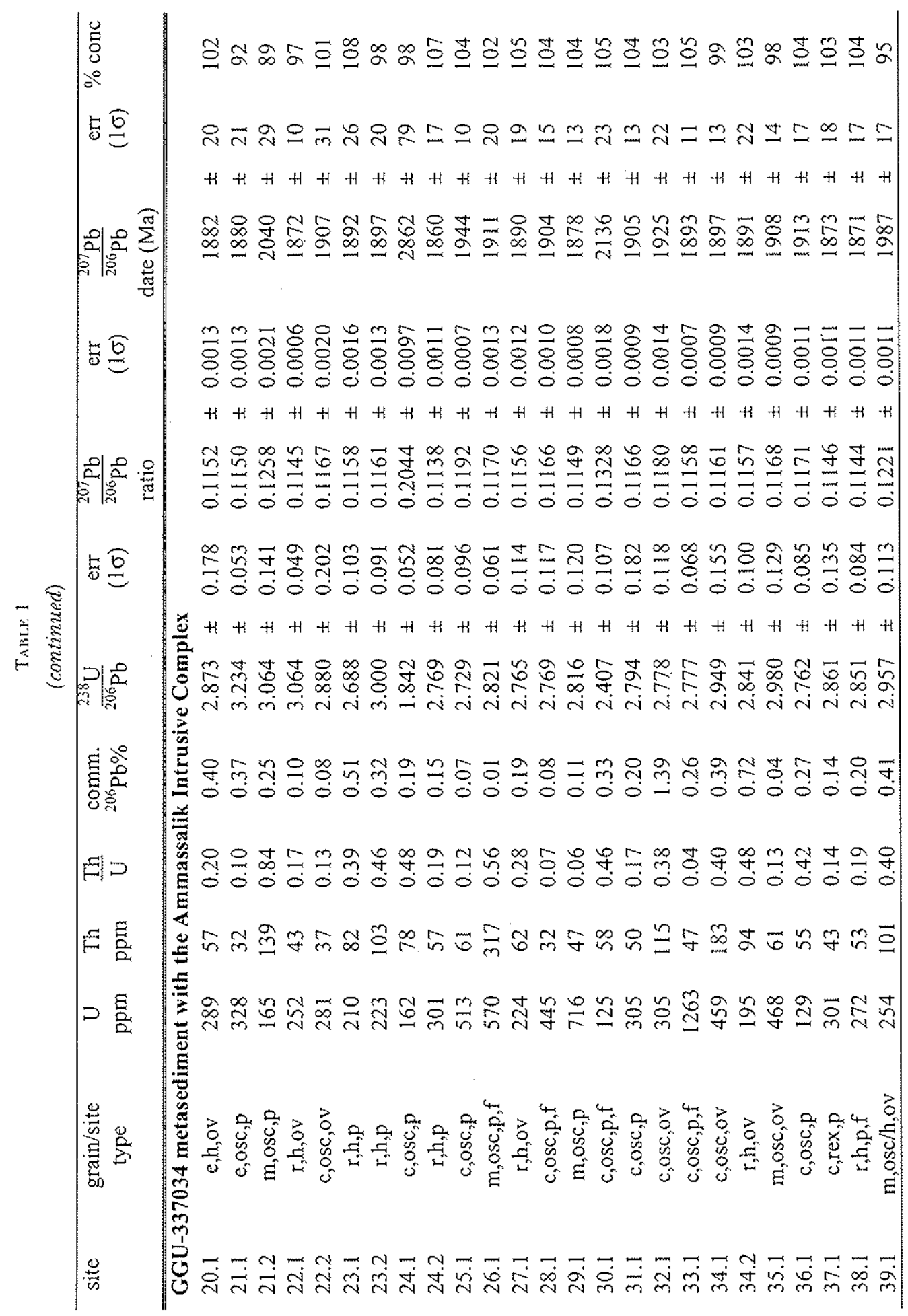


546 A. P. Nutman and others-The Nagssugtoqidian Orogen in South-East Creenland:

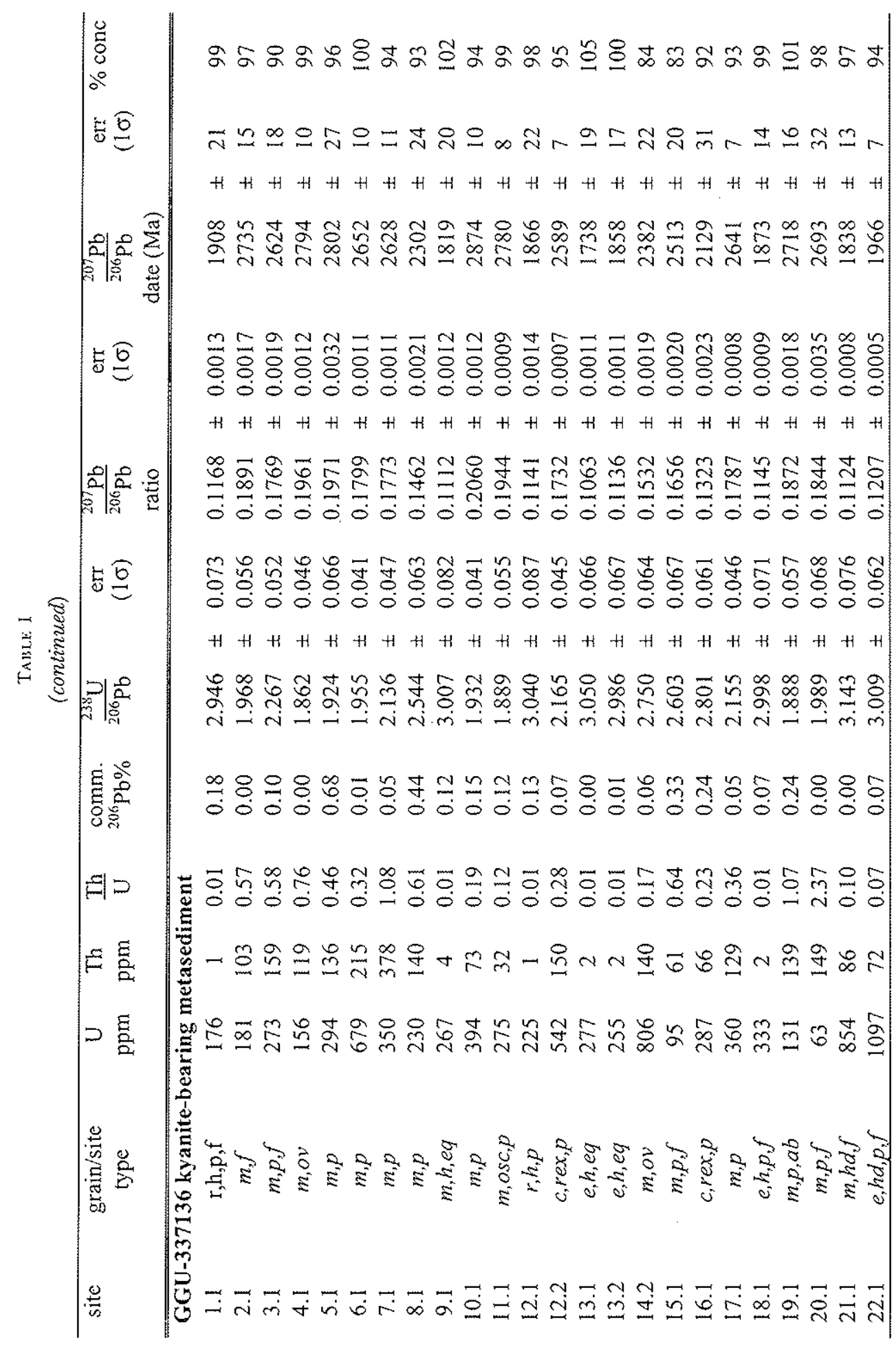




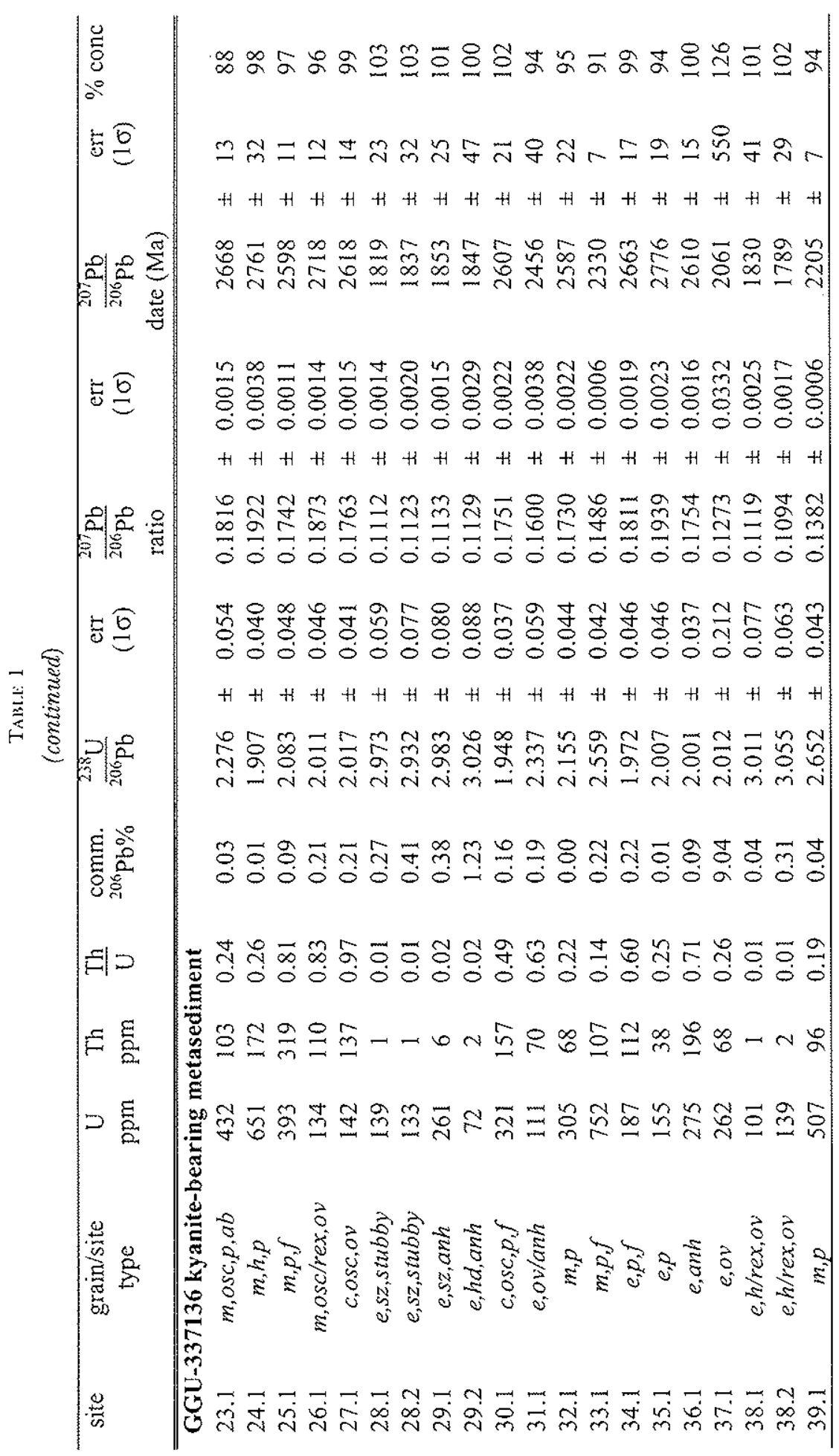




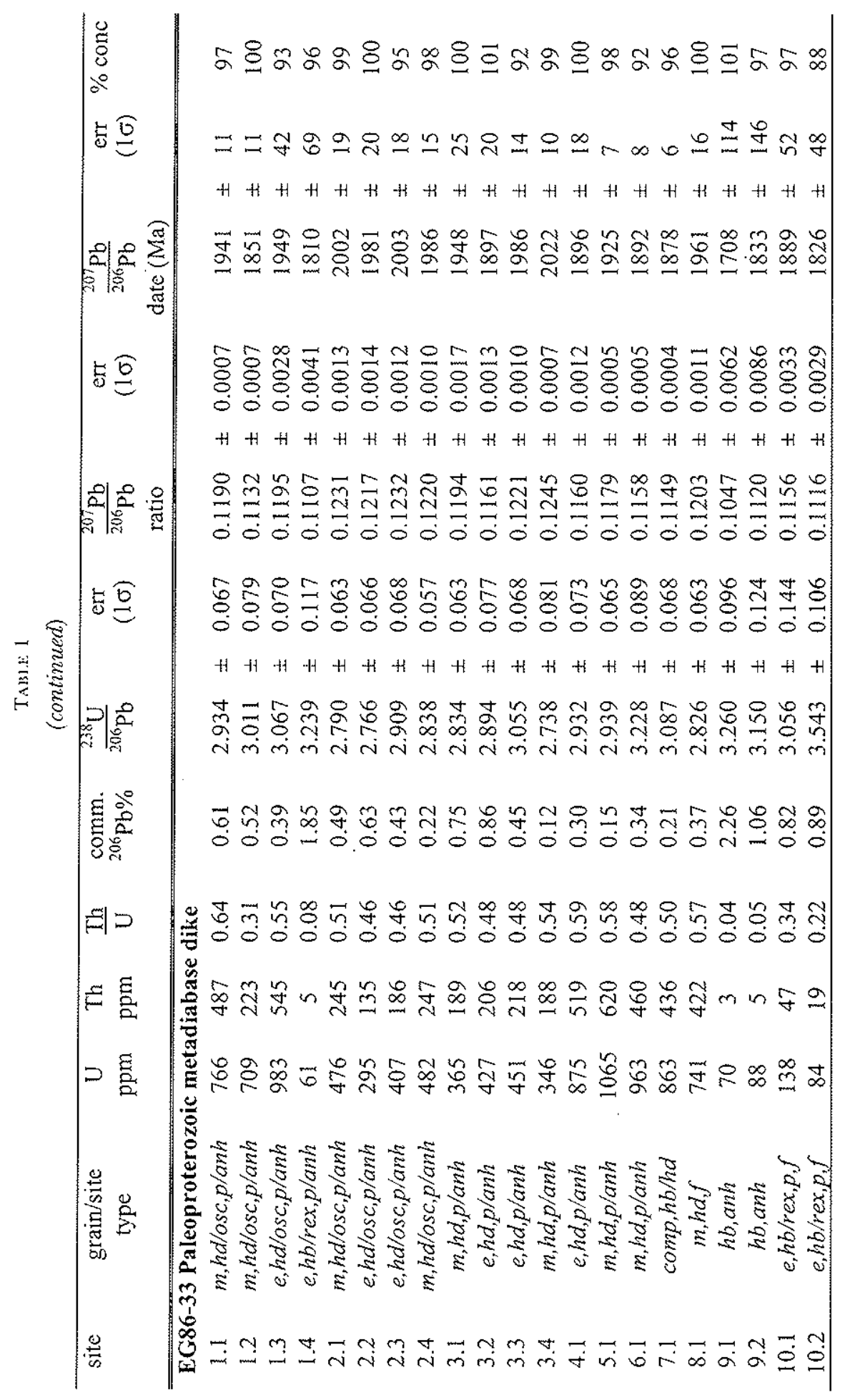




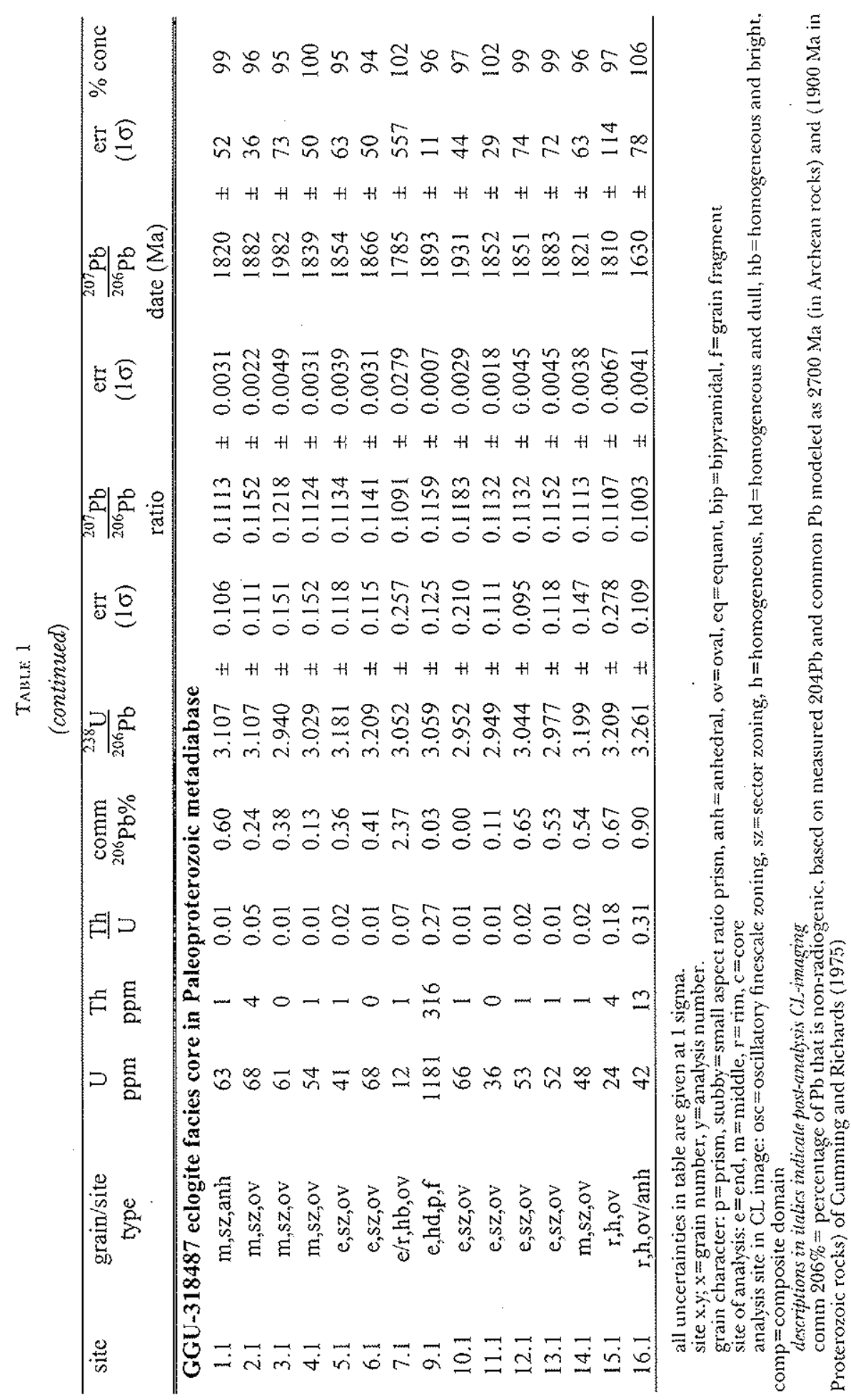


550 A. P. Nutman and others--The Nagssugtoqidian Orogen in South-East Greenland:

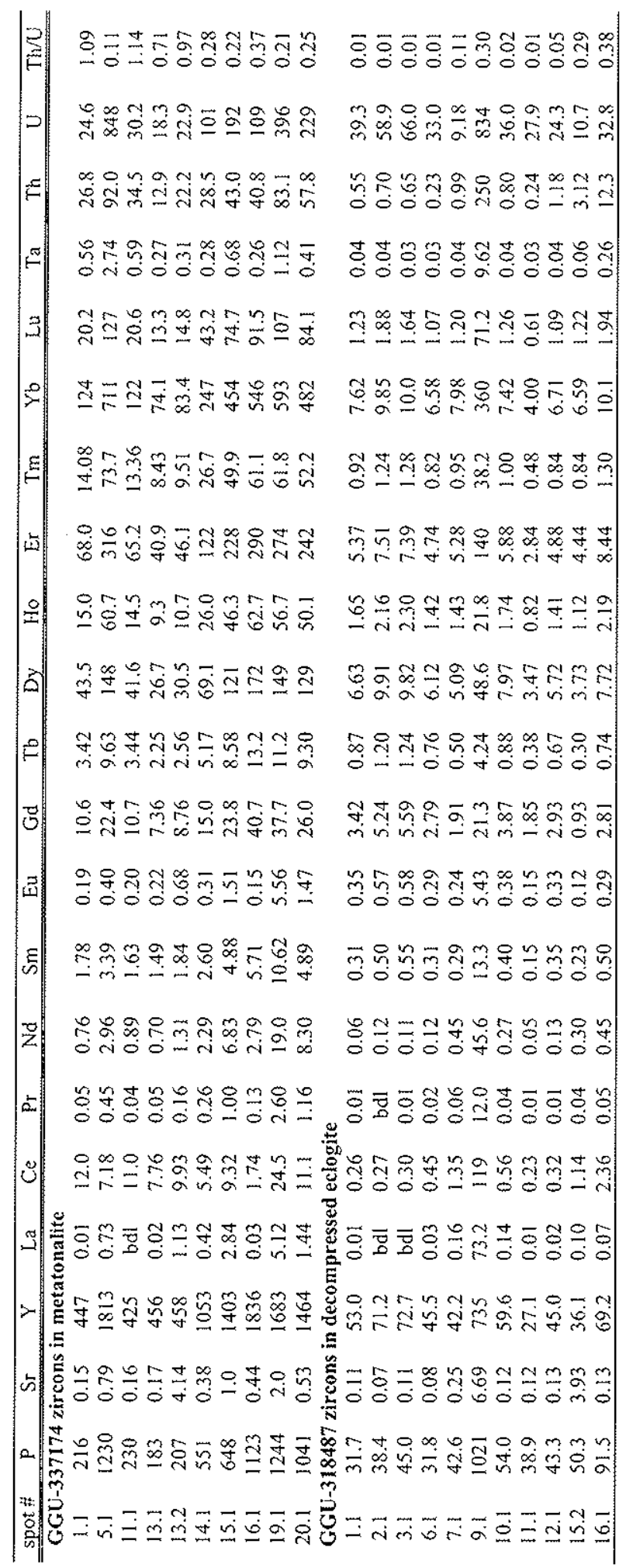



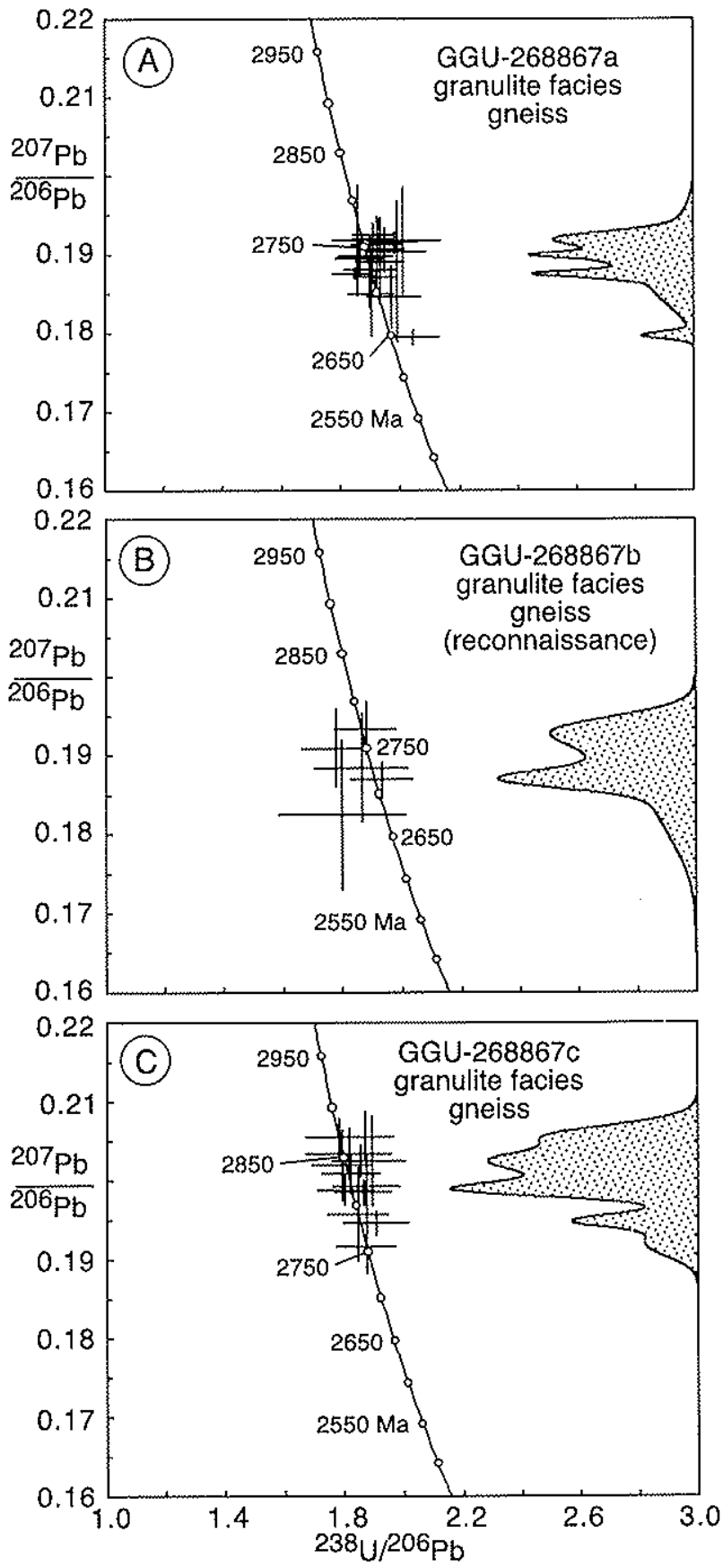

Fïg. 4. Tera-Wasserburg diagrams of SHRIMP U/PB zircon data fiom northern boundary zone orthogneisses $G G U-268867 \mathrm{a}, \mathrm{b}$ and $\mathrm{c}(\mathrm{A}, \mathrm{B}$ and $\mathrm{C}$ respectively). Analytical errors are depicted at 2 sigma. Inset on the right hand side of each frame slows the comulate frequency distribution for ${ }^{207} \mathrm{~Pb} /{ }^{206} \mathrm{~Pb}$ (aftes correction for common $\mathrm{P}$ l) 


\section{A. P. Nutman and others-The Nagssugtoqidian Orogen in South-East Greenland:}

Zircons in these samples are mostly prismatic and up to 200 to $300 \mu \mathrm{m}$ long, brown prisns dominated by oscillatory zoned domains, with variably developed mantles of homogeneous to sector zoned zircon. In some cases these form only narrow skins over the oscillatory-zoned zircon, whereas in other grains the mantles are broader and amenable to analysis using a ca. $30 \mu \mathrm{m}$ SHRIMP spot. Twenty analyses were undertaken on zircons firom GGU-268867a, five analyses on GGU-268867b zircons and thirteen analyses on GGU-268867c zircons (table l and fig. 4). In GGU-268867a multiple analyses of the outer rims of zircons visible by transmitted light microscopy were undertaken, in order to detect if any high-grade metamorphism affecting these rocks occurred in the Paleoproterozoic. However all such analyses yielded Neoarchean ages (table 1). Eight low- Th/U mantles in sample GGU-268867a yielded a spread in ages, but five gave a weighted mean ${ }^{207} \mathrm{~Pb} /{ }^{206} \mathrm{~Pb}$ age of $2720 \pm 6 \mathrm{Ma}(\mathrm{MSWD}=1.01$ ), two gave older ages close to the age of the oscillatory zoned zircon and one gave an age of circa $2650 \mathrm{Ma}$. Interior oscillatory zoned zircon domains all yielded Neoarchean ages. In samples GGU -268867a oscillatory zircon is $2756 \pm 6 \mathrm{Ma}(\mathrm{n}=11, \mathrm{MSWD}=0.88$, with one rejection) and in GGU-268867b $2734 \pm 34 \mathrm{Ma}(\mathrm{n}=5 ; \mathrm{MSWD}=3.3)$, which are interpreted as the age of the igneous protoliths of these gneisses. The oscillatory zoned zircon in sample GGU-268867c is some $100 \mathrm{Ma}$ older. If the spread of measured ${ }^{207} \mathrm{~Pb} /{ }^{207} \mathrm{~Pb}$ in the zircons from this sample is atuibuted to some loss of radiogenic $\mathrm{Pb}$ during a circa $2720 \mathrm{Ma}$ metamorphic event, then the presumed least disturbed analyses with the highest ${ }^{207} \mathrm{~Pb} /{ }^{206} \mathrm{~Pb}$ yield a weighted mean ${ }^{207} \mathrm{~Pb} /{ }^{206} \mathrm{~Pb}$ age of $2863 \pm$ $11 \mathrm{Ma}$ ( $\mathrm{n}=5$; MSWD $=0.89$ ), which is interpreted as the minimum age of the igneous protolith of this gneiss (even the least disturbed zircons may have lost some radiogenic $\mathrm{Pb}$ ). The results from these closely spaced samples support previous conclusions that (1) the Archean orthogneisses are polyphase in nature, with rocks of different ages occurring side by side, and (2) that at ca. $2720 \mathrm{Ma}$ the granulite facies metamorphism in the northern fringe of the orogen is Neoarchean, rather than Paleoproterozoic (Kalsbeek and others, 1993).

\section{Orthogneisses Prewiously Termed 'Blokken gneisses'}

Sample GGU-232884a $\left(65^{\circ} 53.4^{\prime} \mathrm{N}, 36^{\circ} 47^{\prime} \mathrm{W}\right)$ from the previously termed 'Blokken gneisses' has a $\mathrm{Nd} \mathrm{T}_{\mathrm{DM}}$ value of $3010 \mathrm{Ma}$, suggesting predominance of Archean crustal components, and zircon dating of GGU-232884c and have yielded discordant ages with best-fit upper intersections at circa 2920 and $2960 \mathrm{Ma}$, respectively (Kalsbeek and others, 1993). Lower intercepts with Concordia were circa 1470 and $1900 \mathrm{Ma}$, both with a wide margin of uncertainty. Thus the previously temed 'Blokken gneisses' are almost certainly Archean in age, whereas the bulk zircon lower intercepts with Concordia indicate new Paleoproterozoic zircon growth or Pb-loss from Archean zircon. The protolith age of one previously termed 'Blokken gneiss' and its metamorphic history were examined by dating zircons from sample GGU-232884e by SHRIMP.

GGU $232884 \mathrm{e}$ yielded abundant 150 to $300 \mu \mathrm{m}$ prismatic zircons dominated by weakly oscillatory domains, with the layering concordant to grain boundaries (fig. 5A). Irregular recrystallization domains overprint the oscillatory zoning, Most gxains have CL-bright mantles (low $U$ content), that generally are too narrow $(<5 \mu \mathrm{m}$ ) for analysis by SHRIMP. All analyses yielded Archean ages, although all rims that were wide enough were analyzed. The oscillatory zoned zircon cores and whole grains yielded a spread of ${ }^{207} \mathrm{~Pb} /{ }^{206} \mathrm{~Pb}$ ages (fig. $6 \mathrm{~A}$ ), which is interpreted as a result of partial loss of radiogenic $\mathrm{Pb}$ in an ancient event. Accepting this model, the eight sites with the oldest ${ }^{207} \mathrm{~Pb} /{ }^{206} \mathrm{~Pb}$ ages and with an MSWD $<1$ yielded a weighted mean ${ }^{207} \mathrm{~Pb} /{ }^{206} \mathrm{~Pb}$ age of $3035 \pm 14 \mathrm{Ma}$. This is interpreted as close to the age of the igneous protolith. Analyses of the low $\mathrm{Th} / \mathrm{U}$, low $\mathrm{U}$ nims that are CL-bright yielded Archean ages. Those with low common Pb content yielded a weighted mean ${ }^{207} \mathrm{~Pb} /{ }^{206} \mathrm{~Pb}$ age of $2723 \pm 49 \mathrm{Ma}(\mathrm{n}=5 ; \mathrm{MSWD}=0.07)$. This is 

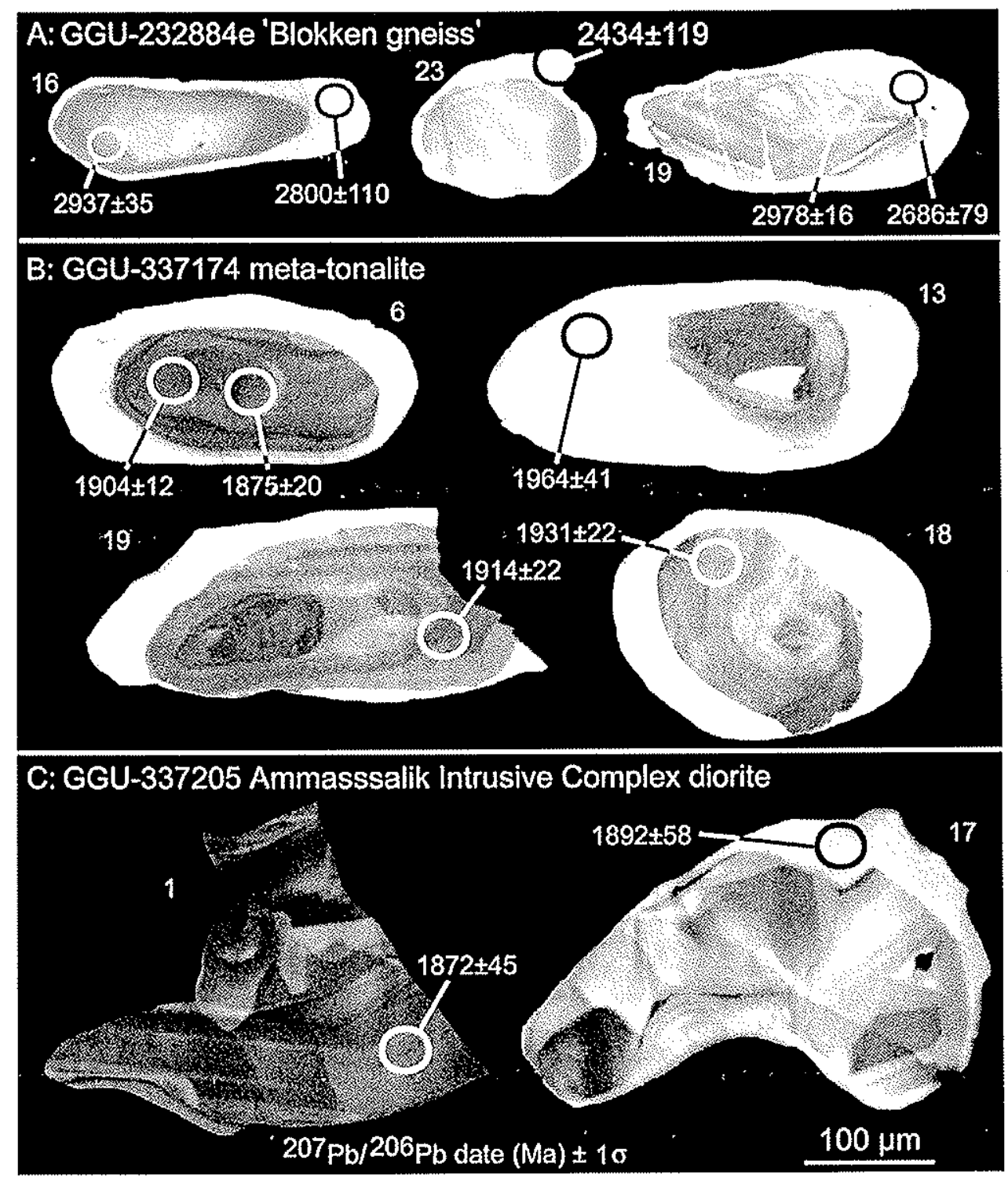

Iig. 5. Cathodoluminescence images of representative zircons from (A) previously-terned Blokken gneiss sample GGU-232884e, (B) Metatonalite GGU-337174, (C) Ammassalik Intrusive Complex diorite GGU -337205

interpreted as giving the time of zircon growh/recrystallization during a Neoarchean high-grade (granulite facies?) metamorphic event. Evidently, the Paleoproterozoic disturbance of the $\mathrm{U} / \mathrm{Pb}$ isotope systematics of the zircons seen in the bulk zircon results (Kalsbeek and others, 1993) is restricted to some loss of radiogenic Pb, rather than new zircon growth.

\section{Paleoproterozoic Meta-tonalites}

GGU 337174 is from an outcrop of garnetiferous tonalitic rocks west of Sermilik $\left(66^{\circ} 06.8^{\prime} \mathrm{N}, 38^{\circ} 04^{\prime} \mathrm{W}\right)$. Bulk zircon fractions from samples 337169 and 337174 of these 
554 A. P. Nutman and others-The Nagssugtoridian Orogen in South-East Creenland:
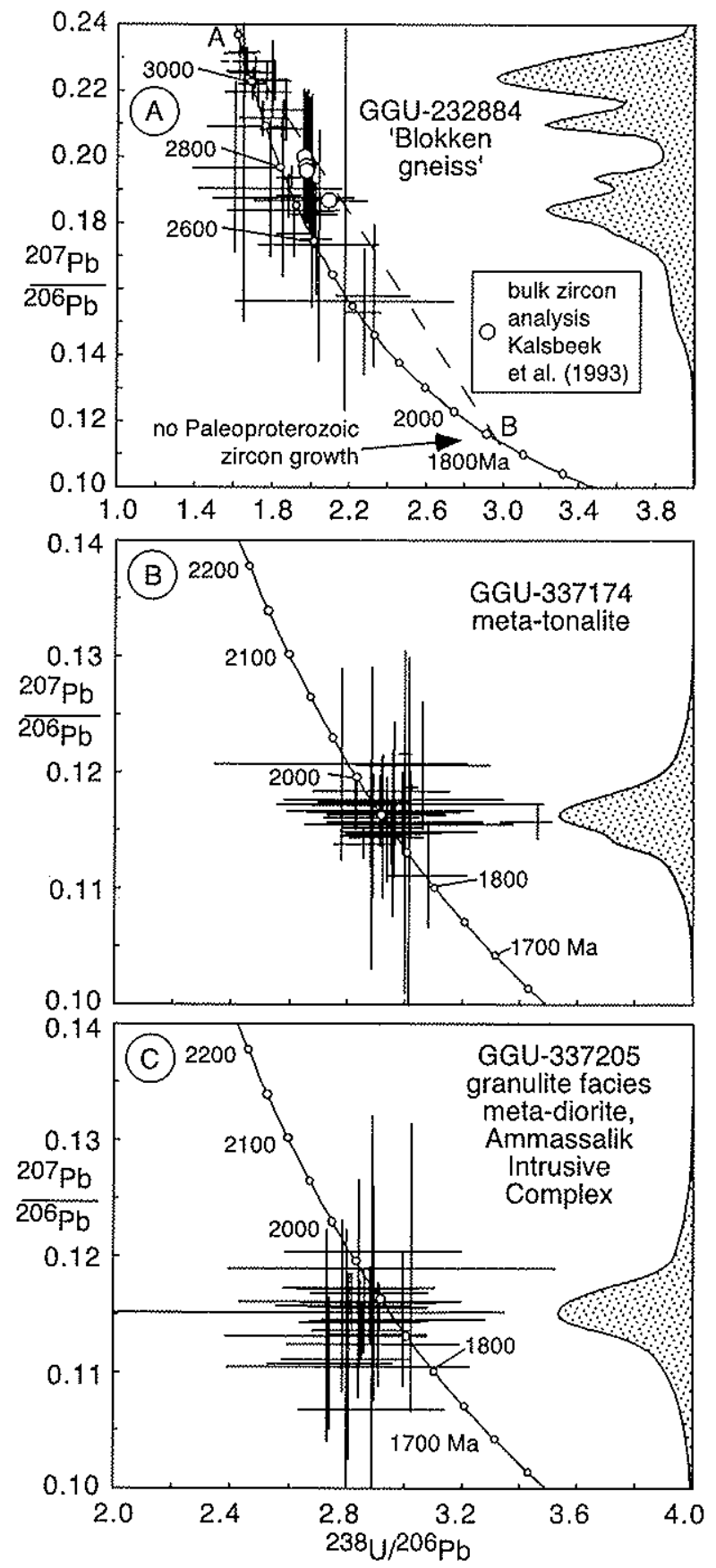

Fig. 6. Tera-Wasserburg diagrams of SHRIMP $\mathrm{U} / \mathrm{Pt}$ ) zircon data from (A) Blokken gneiss sample GGU-232884e. Multigrain IDTMS data (Kalsbeek and others, 1993) is plotted with small circles. (B) Metatonalite 337174. (C) Ammassallk intrusive complex diorite GGU-337205. Analytical errors ałe dejicted at 2 sigma. Inset on the right hand side of each frame shows the cumulate frequency distribution for

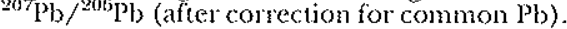


tonalites have yielded slightly discordant Paleoproterozoic ages, 1922 and $1850 \mathrm{Ma}$, and $T_{10 \mathrm{M}}$ values of 2170 and $2190 \mathrm{Ma}$ have been obtained from other samples of the same locality (Kalsbeek and others, 1993).

Zircons in GGU-337174 contain kernels of oscillatory-zoned zircon with often broad mantles that appear brighter and more homogeneous than the kernels in $\mathrm{CL}$, images (fig. 5B). The oscillatory-zoned kernels have high $\mathrm{Th} / \mathrm{U}$ values and near concordant Paleoproterozoic ages (table 1, fig. 6B). Assuming the spread in ${ }^{207} \mathrm{~Pb} /$ ${ }^{206} \mathrm{~Pb}$ beyond analytical error of these data to be the product of some ancient loss of radiogenic $\mathrm{Pb}$, a group with the highest indistinguishable ${ }^{207} \mathrm{~Pb} /{ }^{2065} \mathrm{~Pb}$ yielded a weighted mean age of $1901 \pm 9 \mathrm{Ma}(n=19$; MSWD $=0.64$, one reject). This is interpreted as the formation age of the tonalite protolith to this gneiss. The mantles and replacement domains that appear bright and homogeneous in CL images are lower in $U$ with somewhat lower Th/U (table 1). Four out of five analyses of such sites yielded a weighted mean ${ }^{207} \mathrm{~Pb} /{ }^{206} \mathrm{~Pb}$ date of $1840 \pm 56 \mathrm{Ma}$ (MSWD $=0.36$ ). This indicates that zircons in this rock were recrystallized late in the magmatic event or during a high grade metamorphism shortly afterwards.

LA-ICP-MS trace element analyses were undertaken on the zircons in order to gain further information on zircon recrystallization events (table 2). All analyses display' negative Eu anomalies (fig. 7A) indicating equilibration with plagioclase in both igneous zircon growths and metamorphic recrystallization. Both oscillatoryzoned kernels and the more homogeneous grain margins show strong enrichment of the HREE over the LREE. The degree of HREE enrichment in some recrystallization domains is as high as that in some igneous domains, despite the tendency for trace elements to be expelled when zircons recrystallize. This process did not involve a change in $\mathrm{Gd} / \mathrm{Lu}_{(\mathrm{N})}$ of the zircons (fig. 7A), showing no change in the role of garnet as a coexisting phase during the crystallization history of the zircons. The trace element data demonstrate that the sporadic occurrence of garnet in this suite did not influence the REE spectra in the zircons.

\section{Ammassalik Intrusive Complex Dionite}

GGU-337205 is a diorite from the Ammassalik Intrusive Complex. It was taken from a unit of homogeneous undeformed orthopyroxene-bearing diorite from the quarxy in Ammassalik town $\left(65^{\circ} 36.5^{\prime} \mathrm{N}, 37^{\circ} 38^{\prime} \mathrm{W}\right)$. Bulk zircon analyses of this sample yielded a close to concordant Paleoproterozoic age, with a Concordia intercept age of $1886 \pm 2 \mathrm{Ma}$ (Hansen and Kalsbeek, 1989). The zircons from GGU-337205 are large $(200-500 \mu \mathrm{m})$ pi isms and prism fragments, with widely developed oscillatory-zoning. However, this zoning is disrupted by homogeneous to blotchy-textured domains that appear bright in CL images (fig. 5C). All analyses yielded close to concordant Paleoproterozoic dates (table 1, fg. 6C). All oscillatory-zoned zircon analyses yielded a weighted mean ${ }^{207} \mathrm{~Pb} /{ }^{206} \mathrm{~Pb}$ date of $1881 \pm 10 \mathrm{Ma}(\mathrm{n}=17$; MSWD $=0.92)$ that is interpreted as the age of intrusion. With one analysis rejected, those of the bright in CL domains have lower $U$ contents and yielded a weighted mean ${ }^{207} \mathrm{~Pb} /{ }^{206} \mathrm{~Pb}$ date of $1905 \pm 49 \mathrm{Ma}(\mathrm{n}=7 ; \mathrm{MSWD}=0.79)$, which within its large uncertainty is indistinguishable from the age of igneous crystallization.

\section{Provenance and Melamorphic History of Sillimanite and Orthopyroxene Bearing Metasedimentany Rocks Associated with the Ammassalik Intrusive Complex}

Garnet + sillimanite + orthopyroxene bearing metasedimentary rocks along the southern edge of the Ammassalik Intrusive Complex (fig. 1) contain extensive garnetbearing granitic melt domains that migrate and mingle with the diorites of the Complex. Thus from field relationships it appears that melting in the metasediments was triggered by emplacement of the Ammassalik Intrusive Complex. IDTIMS analyses 


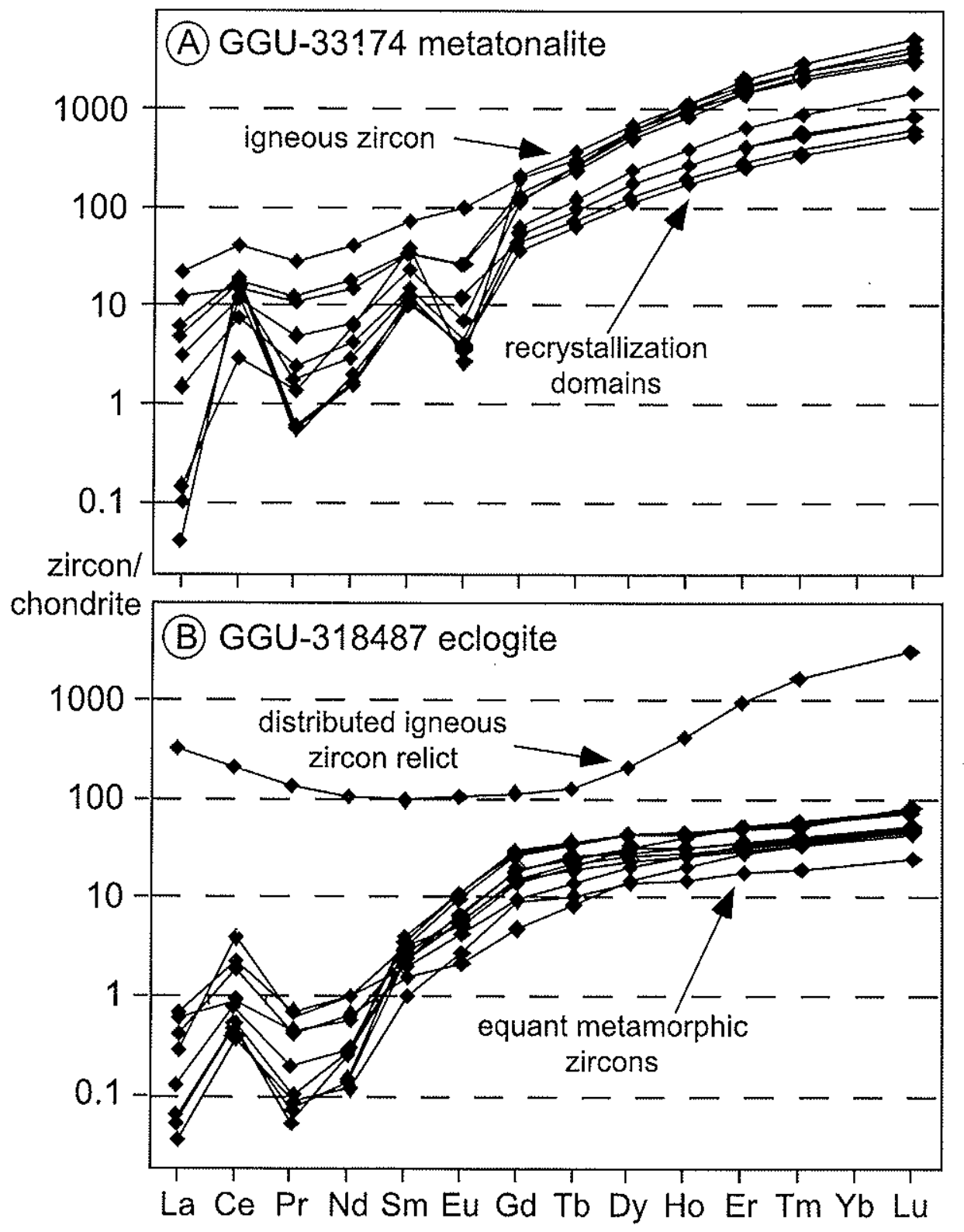

Fig. 7. Chondrite nomalized plots of I.A-ICP-MS REE anafyses. (A) zircons from Paleoproterozoic tonalite 337174. (B) metamorphic zircons from eclogite facies domain in Paleoproterozoic metadiabase dike 318487 .

of bulk zircon fractions from garnet-granite gneiss GGU-337041 yielded an upper intersection with Concordia at $1900^{+25}-35 \mathrm{Ma}$ and a lower intersection at $\sim$ zero, with ${ }^{207} \mathrm{~Pb} /{ }^{206} \mathrm{~Pb}$ ages between 1913 and $1903 \mathrm{Ma}$ (Kalsbeek and others, 1993). This age agrees with those obtained from the Ammassalik Intrusive Complex and supports the field interpretation that melting of metasedimentary gneisses was triggered by intru. sion of the complex. 

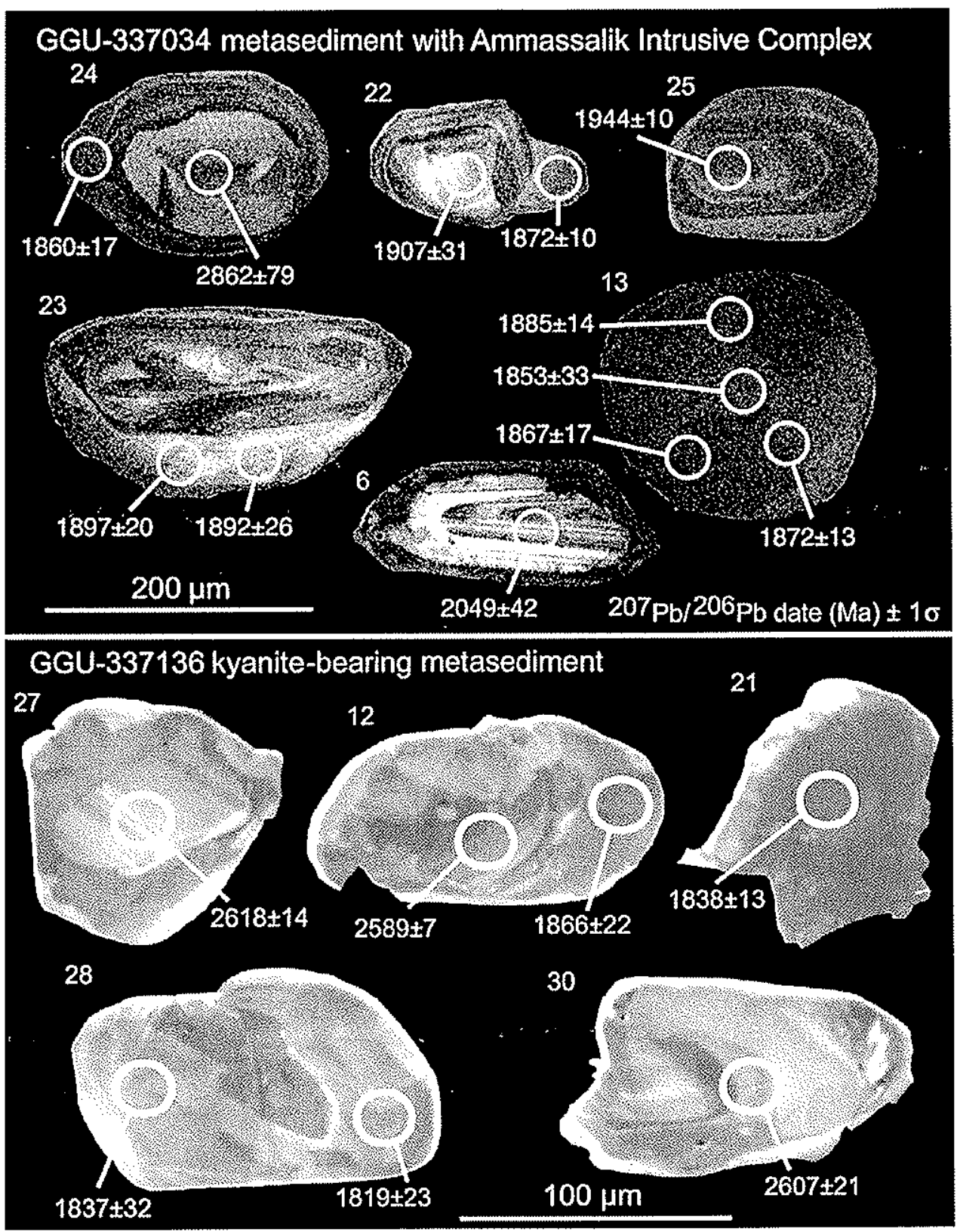

Fig. 8. Cathodoluminescence images of representative zircons from (A) diatectic metasedimentary gneiss GGU-337034 associated with the Ammassalik intrusive complex and (B) kyanite-bearing metasediment GGU - 337136 .

Provenance of the metasedimentary rocks and their metamorphic history was examined further by zircon dating of diatectic garnetiferous metasediment GGU337034. In CL images the zircons often display complex structure, with more than one structual domain (fig, 8A). Rounded and truncated oscillatory-zoned cores are obvious in some grains, whereas in others a kernel of oscillatory zoned zircon with 
558 A. P. Nutman and others-The Nagssugtoqidian Orogen in South-East Greenland:

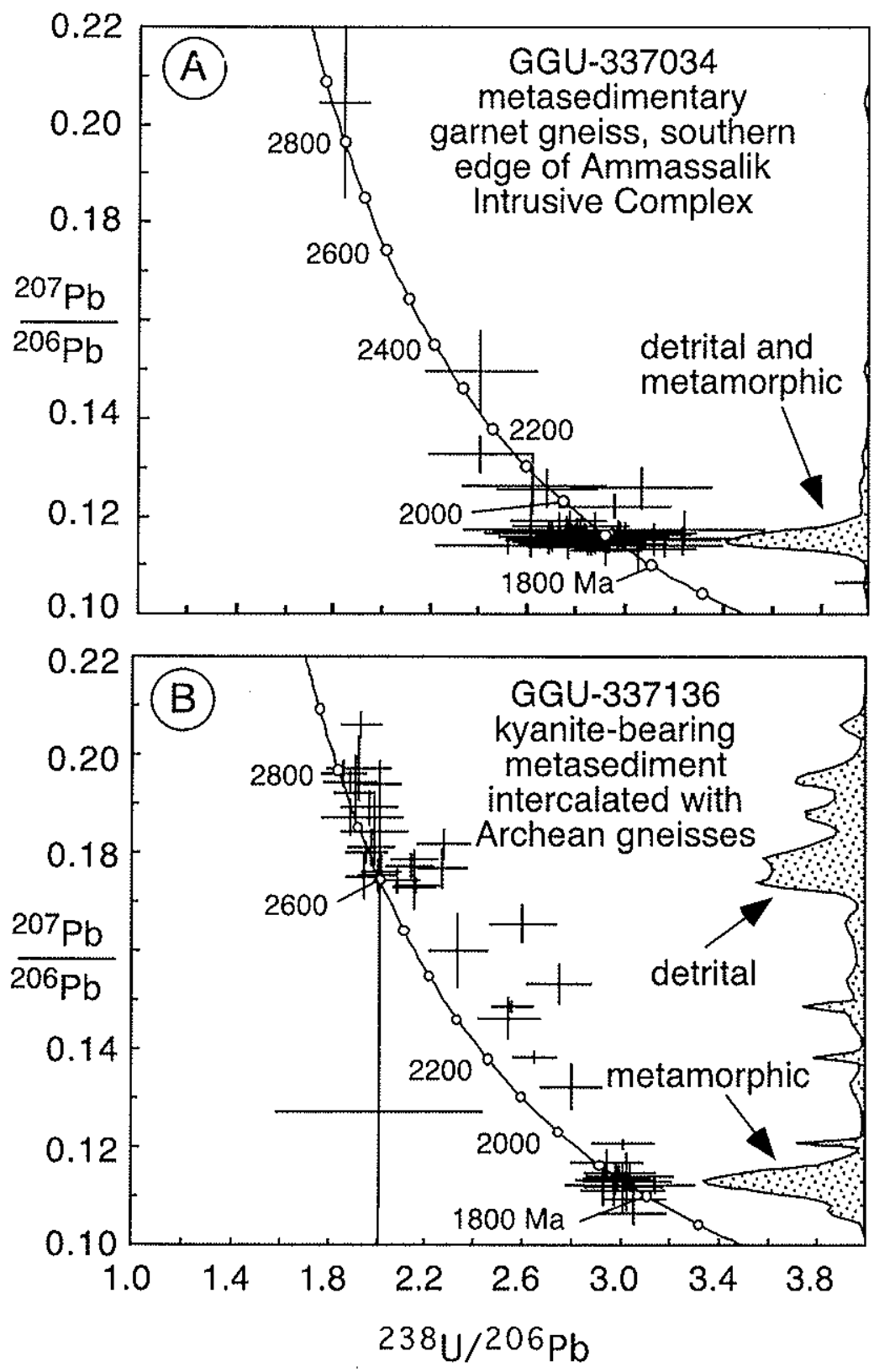

Fig. 9. Tera-Wasserburg diagram of SHRIMP U/Pb zircon data from kyanite-bearing metasediment GGU-337136. Analytical errors are depicted at 2 sigma. Inset on the right hand side of the frame shows the cumblate frequency distribution for ${ }^{207} \mathrm{~Pb} / 206 \mathrm{pb}$ (atier correction for common $\mathrm{Pb}$ ).

zoning more or less parallel to grain boundaries is mantled by domains of more homogeneous zircon. There are also some equant, structureless grains. Fifty analyses were undertaken of all types of zircon domain, with thirty-nine grains being studied (table I, fig. 9A). Only one Archean core (grain 24) was detected, with all other zircon yielding Paleoproterozoic ages, mostly of 1950 to $1850 \mathrm{Ma}$, with only a few giving 
slightly older ages (for example, grain 6 with an age of circa $2050 \mathrm{Ma}$ ). For zircon of undoubted detrital origin that forms rounded cores in grains with truncated oscillatory zoning (for example, grain 6, fig. 8A) youngest ages were circa $1910 \mathrm{Ma}$ (for example, analyses 35.1 and 36.1$)$. Outermost mantles on grains are generally least structured in CL images (for example, the protuberance on grain 22, fig. $8 \mathrm{~A}$ ). There are also a few equant grains that are structureless and Cl-dull (grain 13, fig. 8A). These domains generally have moderate to low $\mathrm{Th} / \mathrm{U}$. They yield a weighted mean ${ }^{207} \mathrm{~Pb} /{ }^{206} \mathrm{~Pb}$ age of $1874 \pm 8 \mathrm{Ma}(95 \%$ confidence, MSWD $=0.41)$. This is taken to mark zircon growth and recrystallization during a high grade metamorphic event. It should be noted that this age population does not contain any oscillatorymoned zircon. There are also other abundant zircon domains, which structurally appear older than the $1874 \pm \mathrm{Ma}$ metamorphic domains, yet do not form obvious rounded $>1910$ Ma cores. This zircon shows a range of morphology and Th/U. Some domains (for example the main part of grain 22, fig. 8A) are oscillatory zoned, with zoning parallel to grain margins. Other domains are homogeneous generally Clrbright (low U), and can form rims or recrystallization domains (for example on grain 23, fig. 8A). These domains are intermediate in age between the $1874 \pm 9 \mathrm{Ma}$ rims and equant grains, and cores definitely of devital origin. We intexpret this complex suite of zircon domains to have grown during the diatexis event that affected this rock. We contend that the unrounded oscillatory-zoned zircons grew in neosome melt domains, and the structureless rims and equant grains grew sub-solidus in paleosome. This age is indistinguishable from that of the Ammassalik Intrusive Complex. Thus it appears that the sedimentary protolith of this rock carried mostly Paleoproterozoic detrital zircons, with only rare Archean grains. It was affected by diatexis at the time the Ammassalik Intrusive Complex was intruded, and then by further metamorphism, approximately 25 million years later.

\section{Provenance and Metamorphic History of Kyanite-Bearing Metasedimentary Rocks Intercalated with Archean Gneisses}

GGU-337136 is a garnet- and kyanite-bearing paragneiss from a circa $200 \mathrm{~m}$ wide layer of metasedimentary rocks embedded in orthogneisses of probable Archean age at Augpalugtooq $\left(66^{\circ} 06.5^{\prime} \mathrm{N}, 37^{\circ} 57^{\prime} \mathrm{W}\right.$; fig. 1). The relationship with the surrounding orthogneisses is ambiguous due to high strain. Sm-Nd data on two paragneisses yielded $\mathrm{T}_{1 \mathrm{M}}$ values of 2.88 and $2.75 \mathrm{Ga}$ indicating that they consist mainly of Archean detritus. However, Rb-Si data on 14 samples yielded a well constrained errorchron with a slope corresponding to an age of $1870 \pm 50 \mathrm{Ma}$, and the relatively low initial ${ }^{87} \mathrm{Sr} /{ }^{86} \mathrm{~S}$ ratio of 0.714 strongly suggests that the present high $\mathrm{Rb} / \mathrm{Sr}$ ratios of the samples (mean $\mathrm{Rb} / \mathrm{Sr}=0.94-$ much higher than that of the surrounding gneisses) are probably related to sedimentary processes, and suggest Paleoproterozoic deposition (Kalsbeek and others, 1993).

Dating of zircons from GGU-337136 was undertaken in 1994 without assistance of CL images. However, images were later obtained on some of the previously analyzed grains to aid data interpretation. GGU-337136 yielded abundant small zircons, which reveal complex structure in CL images (fig. $8 \mathrm{~B}$ ). Centers of grains contain oscillatoryzoned to homogeneous zircon. These are partly replaced and/or overgrown by domains that in Cl. imaging reveal sector zoning or appear homogeneous. These new domains can themselves show complex internal structure (fig. 8B), and might reflect more than one episode of zircon recrystallization and growth. The older oscillatoryzoned zircon can show truncated zonation at grain boundaries, and is interpreted to be detrital in origin. Eight analyses of detrital zircon yielded discordant Paleoproterozoic ages (table 1, fig. 9B), and are interpreted as Archean grains that lost some radiogenic $\mathrm{Pb}$ in the Proterozoic. Analyses of twenty-two other detrital zircons yielded Archean 
ages between 2800 and $2600 \mathrm{Ma}$. Thus the maximum depositional age of the sediment is around $2600 \mathrm{Ma}$. The reciystallization and overgrowth domains generally have low Th/U (table 1) and have close to concordant Paleoproterozoic ages. These domains show a dispersion of ${ }^{207} \mathrm{~Pb} /{ }^{206} \mathrm{pb}$ ages beyond that expected from a single population, in keeping with their complex structure in $\mathrm{Cl}$ images. Using the unmix routine of Isoplot, three age components of $1740 \pm 40(9 \%), 1835 \pm 19(59 \%)$ and $1874 \pm 23 \mathrm{Ma}$ $(32 \%)$ were extracted. Although the age of any of these components might be open to debate, clearly the zircons suffered complex reciystallization and regrowth in the Paleoproterozoic. One age component $(1740 \pm 40 \mathrm{Ma})$ is similar to $\mathrm{a} \mathrm{Pb} / \mathrm{Pb}$ whole rock isochron age (1773 $\pm 22 \mathrm{Ma}$ ) obtained from marbles from the northern part of the mobile belt by Taylor and Kalsbeek (1990). The zircon geochronology places the deposition of the sediment between c. 2600 and c. $1900 \mathrm{Ma}$. Therefore it is unlikely to be an integral component of the Neoarchean gneiss complex, but instead belongs to an early Paleoproterozoic cover sequence.

Age and Metamorphic History of Paleoproterozoic Metadiabase Dikes

Sample EG86-66 is a fractionated felsic domain in a metadiabase dike from the northern coastal part of the orogen, and was collected by the late David Bridgwater (fig. 1). Regrettably, with David's death, more detailed field information on this sample is not available. It gave a small yield of prismatic to jagged anhedral zircons (fig. 10A). This habit is typical of zircons in gabbros (Poldervaart, 1956), and probably indicates growth in late interstitial melt domains of local zircon saturation. In CL images the zircons contain interior domains that appear dull, but locally display weak oscillatory zoning. These are partially replaced and overgrown at their margins by domains that are bright and homogeneous or patchy in CL images (fig. 10A). The interior domains are interpreted to be of igneous origin, whilst the bright exterior domains are interpreted to have developed by recrystallization and perhaps regrowth during metamorphism. Analyses of CL-dull domains have moderate to high U content $(1100-300 \mathrm{ppm})$ and high Th/U $(0.65-0.4)$, with a spread of ${ }^{207} \mathrm{~Pb} /{ }^{206} \mathrm{pb}$ ages between circa $2020 \mathrm{Ma}$ and $1800 \mathrm{Ma}$ (table 1, fig. 11A). Multiple analyses on some of the grains suggest this spread is due to variable partial ancient loss of radiogenic $\mathrm{Pb}$ from one generation of zircon. Three analyses with the oldest ${ }^{207} \mathrm{~Pb} /{ }^{206} \mathrm{~Pb}$ yield a weighted mean date of $2015 \pm 15 \mathrm{Ma}(\mathrm{MSWD}=0.69)$. This is interpreted to approach the time of intrusion of the metadiabase dike. All the CL-bright domains have lower $U$ concentrations and yield a weighted mean ${ }^{207} \mathrm{~Pb} /{ }^{206} \mathrm{~Pb}$ age of $1836 \pm 58 \mathrm{Ma}(\mathrm{n}=5$; $M S W D=0.62$ ). This is interpreted as the time of zircon recrystallization during metamorphism.

Sample GGU-318487 of an eclogite facies domain in a dike north of the Ammassalik Intrusive Complex (fig. 1) yielded small equant zircons that appear homogeneous to sector-zoned in CL images (fig. 10B). The exterior of some grains have thin domains that appear darker in CL images. These were too narrow to analyze with a typical $>20 \mu \mathrm{m}$ SHRIMP spot. A few grains contain small, corroded domains that appear dull in CL images. One SHRIMP analysis attempted on such a domain had the highest $U$ content $(1181 \mathrm{ppm})$ and highest $\mathrm{Th} / \mathrm{U}(0.27)$ with a ${ }^{207} \mathrm{~Pb} /{ }^{206} \mathrm{~Pb}$ date of circa $1900 \mathrm{Ma}$ (grain 9; table 1, fig. 11B). This is interpreted as a small (disturbed) relict of igneous zircon, showing the dike is at least $1900 \mathrm{Ma}$ old. Analyses of the homogeneous to sector zoned zircon (table 1; fig. 11B) have rather low $U$ concentrations (mostly $<70 \mathrm{ppm}$ ) and low $\mathrm{Th} / \mathrm{U}$ (mostly $<0.03$ ) and with rejection of one analysis with an anomalously young age yielded a weighted mean ${ }^{207} \mathrm{~Pb} /{ }^{206} \mathrm{~Pb}$ date of $1867 \pm 28 \mathrm{Ma}(\mathrm{n}=13 ; \mathrm{MSWD}=0.60)$. The dominant homogeneous to sector-zoned zircons contain rare micro-inclusions of quartz, clinopyroxene and Ca-garnet, with no plagioclase inclusions found. LA-ICP-MS trace element analyses of these zircons reveal depressed HREE abundances with no significant negative Eu anomalies (table 2, fig. 

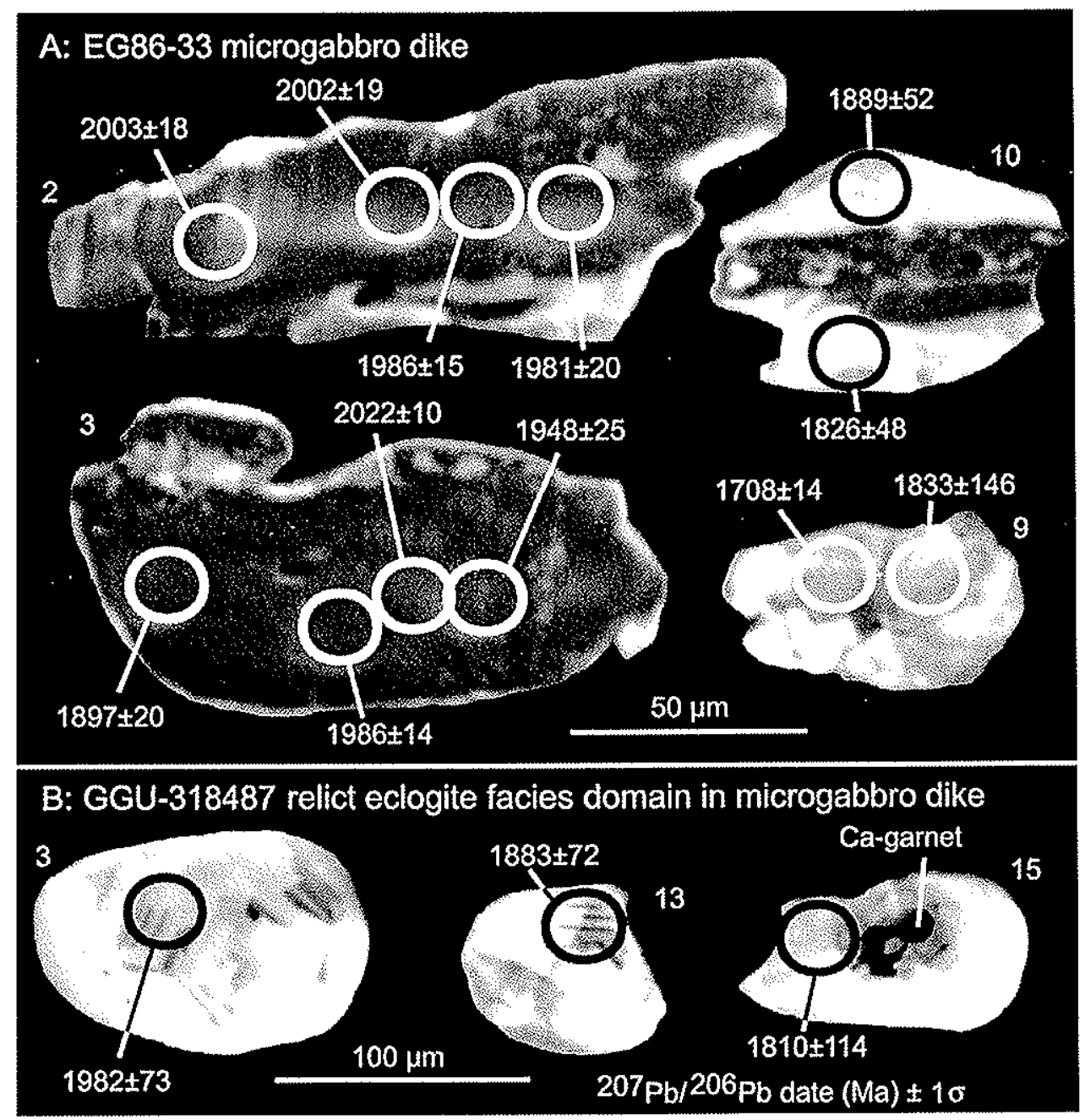

Fig. 10. Cathodoluminescence images of zircons from metadiabase dike samples (A) rG86-66 and (13) GQU-318487.

7B). This indicates zircon growth in a garnet-rich but plagioclase-absent enviromment (Rubatto, 2002). Thus $1867 \pm 28 \mathrm{Ma}$ is interpreted as the time of eclogite facies metamorphism (plagioclase absent), rather than that of growth during subsequent isothermal recrystallization at lower pressures (plagioclase present).

Kalsbeek and others (1993) reported a Sm-Nd garnet-clinopyroxene-whole rock isochron of $1817 \pm 22 \mathrm{Ma}$ for an eclogite remnant in a dike, marginally younger than the $1867 \pm 28 \mathrm{Ma}$ date obtained for the eclogite facies metamorphism here. Petrography of the eclogites indicates high temperature decompression reactions, such as exsolution of albite from originally omphacitic clinopyroxene and the development of orthopyroxene + plagioclase on the edges of garnets (Nutman and Friend, 1989). Thus the $1817 \pm 22 \mathrm{Ma} \mathrm{Sm}-\mathrm{Nd}$ mineral isochron is considered to reflect closure of minerals to $\mathrm{Sm}$ and Nd diffusion along a high temperature decompression path, rather than to date maximum pressure of metamorphism. 

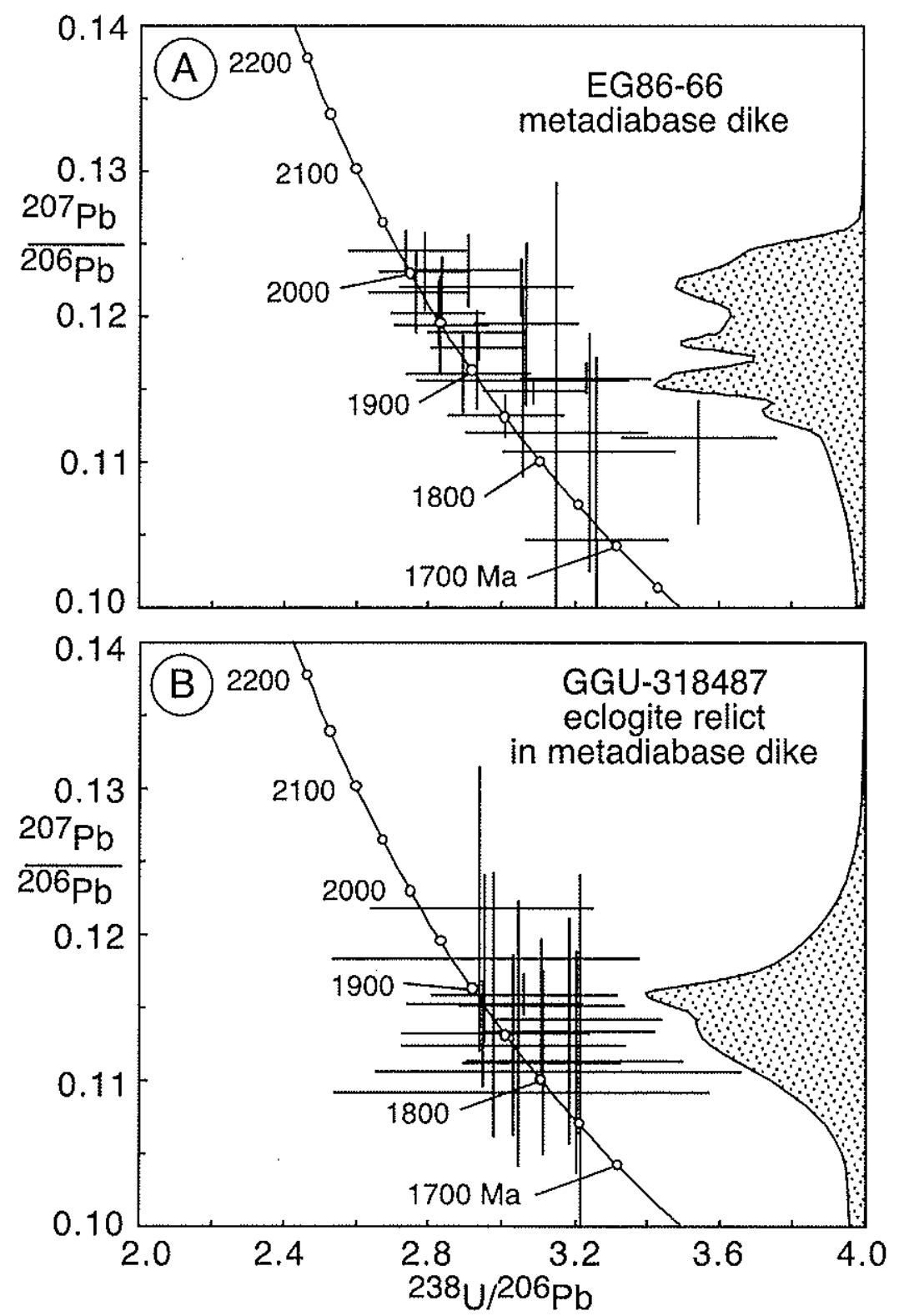

Fig. 11. Tera-Wasserburg diagrams of SHRIMP zircon $\mathrm{U} / \mathrm{Pb}$ data from meladiabase dike samples (A) EG86-66 and (B) GGU-318487. Analytical errors are depicted at 2 sigma. Inset on the righe hand side of each frame shows the cumulate frequency distribution for ${ }^{207} \mathrm{pb} /{ }^{206} \mathrm{pl}$ (after correction for common $\mathrm{Pb}$ ).

\section{DISCUSSION}

\section{Reassessment of the Nagssugtoqidian Orogenic Belt in East Greenland}

The results presented here provide new insights into the history of the Nagssugtoqidian orogen in the Ammassalik region (fig. 12), and support some previous interpretations, but necessitate revision of others. The zircon geochronological results com- 


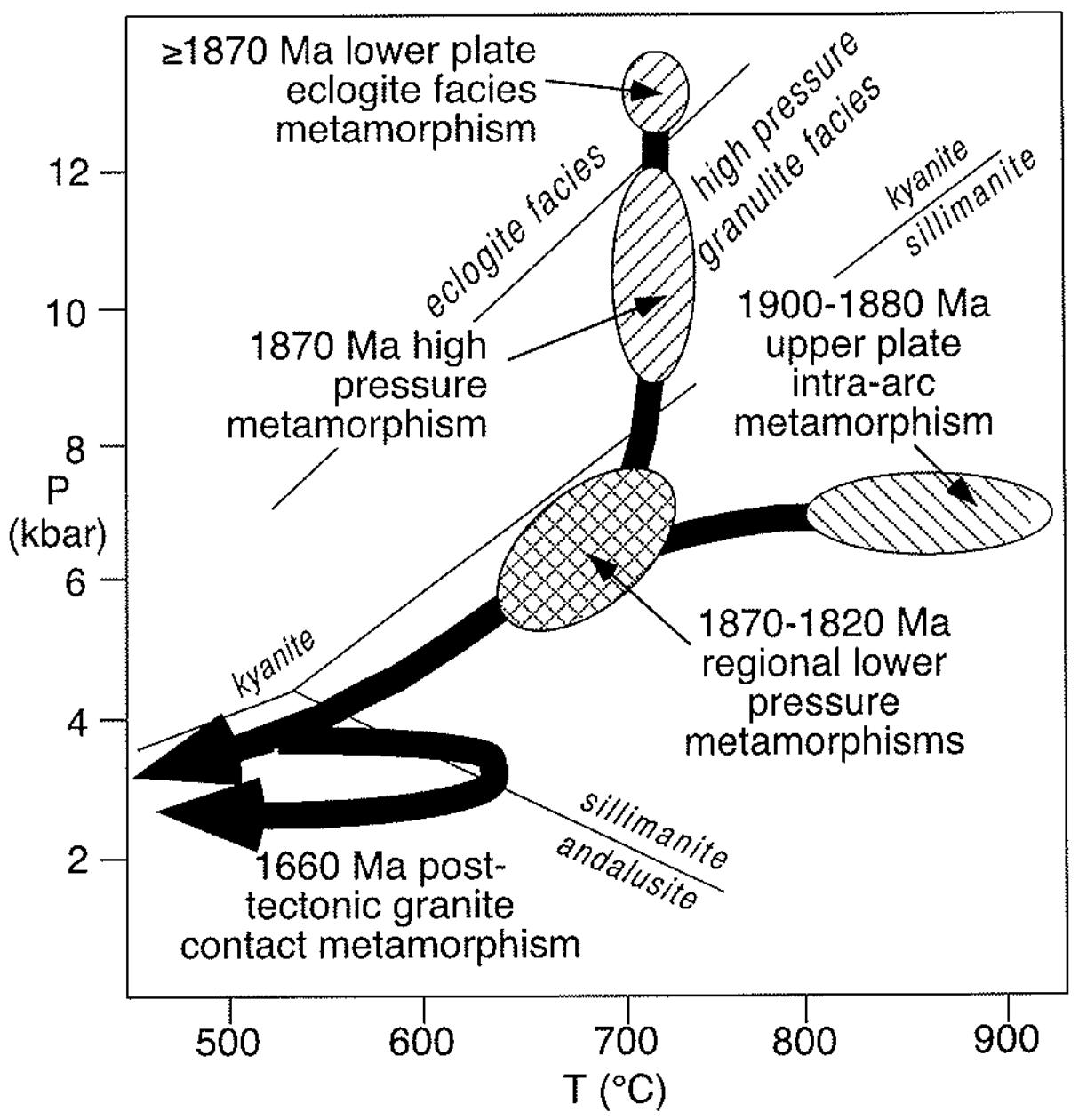

Fig, 12. Paicoproterozoic P-I (pressure-temperature-time) evolution in the Ammassalik region, based on results presented here and by Kalsbeek and others (1993), combined with reassessment of data in Nutman and Friend (1989).

bined with the broader isotopic studies of Kalsbeek and others (1993) confirm that Archean and Paleoproterozoic rocks with contrasting origins and metamorphic histories are present. The new results, particularly the focus on dating of metamorphic rims and recrystallization domains in zircons provides more concrete information on a long and diverse metamorphic history. Thus for Archean rocks in the northern part of the region, circa $2720 \mathrm{Ma}$ is shown to be the time of high-grade (granulite facies) metamorphism. This study reinforces previous work (Kalsbeek and others, 1993) that Archean gneisses in the north of the region (affected by $2720 \mathrm{Ma}$ metamorphism) show different protolith ages $(3035-2750 \mathrm{Ma})$. The Ammassalik Intrusive Complex, which is dominated by juvenile additions to the crust, experienced $1905 \pm 49 \mathrm{Ma}$ LP-HT metamorphism up to granulite facies, probably coeval with its igneous emplacement. On the other hand, structurally underlying Archean gneiss complexes have Palcoproterozoic metadiabase dike remnants that display eclogite facies metamorphism at $1867 \pm 28 \mathrm{Ma}(\mathrm{U} / \mathrm{Pb}$ zircon $)$ with closure to $\mathrm{Sm}-\mathrm{Nd}$ diffusion along a high temperature decompression path at $1817 \pm 22 \mathrm{Ma}$ (Sm-Nd mineral isochron). 


\section{A. P. Nutman and others-The Nagssugtogidian Orogen in South-East Greenland:}

Previously, Friend and Nutman (1989) presented a P-T-t synthesis where the emplacement of the Ammassalik Intrusive Complex and its low-pressure metamorphism were younger than the eclogite facies metamorphism. This followed on from the interpretation of Bridgwater and Myers (1979) that the Ammassalik Intrusive Complex is a late-kinematic intrusion. The accumulated zircon dating now suggest that such a scenario is unlikely, because the Ammassalik Intrusive Complex (1886 $\pm 2 \mathrm{Ma}$ ) appears to be older than the eclogite event ( $1867 \pm 28 \mathrm{Ma}$ - although at the two sigma level the error intervals overlap, the probability of a real age difference is $>90$ percent. Also, by comparison with similar rocks in the Nagssugtoqidian belt of West Greenland for which an arc setting is indicated by geochemical data, we suggest that the Ammassalik Intrusive Complex is a magmatic arc complex dominated by juvenile Paleoproterozoic material (Kalsbeek and others, 1993). This is in accord with data presented here that shows the importance of Paleoproterozoic (2100-1900 Ma) rather than Archaean zircons. It is proposed here that the HT-LP metamorphism in the Ammassalik Intrusive Complex is unique to those rocks, and that it along with associated supracrustal rocks were tectonically emplaced over the edge of a southem terrane of Archean continental crust and cover sequences, which then experienced transient high pressure metamorphism at $1867 \pm 28 \mathrm{Ma}$ (fig. 12). This is consistent with southerly-directed tectonic transport deduced in earlier studies (Chadwick and others, I989). This tectonic emplacement/collision led to the cessation of arc magmatism. Subsequently the Paleoproterozoic juvenile arc rocks, cover sequence and southern Archean basement experienced a common history of folding and amphibolite facies metamorphism (fig. 12). Such a model infers that subduction was northward, meaning that the Ammassalik Intrusive Complex would be a component of an overlying arc. This would place a suture at the structural base of the Ammassalik Intrusive Complex and its carapace of metasedimentary rocks with HT-LP (orthopyroxene grade) metamorphism. This hypothetical suture would not have a simple geometry, because it has been folded at least twice and has entirely or partly been excised by younger shear zones, such as the steeply dipping one at the northern edge of the Complex (fig. 1). This reappraisal supports previous suggestions (Kalsbeek and Taylor, 1989) that the Nagssugtoqidian orogen in East Greenland should contain a (cryptic) suture. Moreover, the occurrence of almost coeval HP and LP metamorphic complexes is a characteristic of Phanerozoic convergent plate boundary processes (Miyashiro, 1973), supporting the Paleoproterozoic plate tectonic scenario explored here for the Ammassalik region.

\section{Comparison of Events of the Nagssugtoqidian in East and West Greenland}

In the 1990s, following on from the geochronological and geochemical study of Kalsbeek and others (1987), a major research initiative in the Nagssugtoqidian of West Greenland found sheared sutures (or one suture repeated by thrusting) between unrelated blocks of Archean basement crust and juvenile Paleoproterozoic arc assemblages (Kalsbeek and Nutman, 1996; van Gool and others, 2002). Where the suture had not been excised by later shear zones, they are commonly marked by metasedimentary rich units rich in marbles (for example, Kalsbeek and Nutman, 1996). These would have made excellent decollements during thrust transport, which has been estimated to be more than $50 \mathrm{~km}$ (Kalsbeek and Nutman, 1996; Manatschal and others, 1998; van Gool and others, 2002). The fundamental nature of these tectonic contacts is illustrated by the common occurrence of peridotite pods of likely mantle origin along them (Kalsbeek and Manatschal, 1999). Detailed zircon geochronology showed that arc magmatism lasted from 1920 to $1870 \mathrm{Ma}$, that the youngest detrital zircons in immature quartzo-feldspathic sediments in the arc assemblages are circa $1900 \mathrm{Ma}$ old, and that regional metamorphism of all units peaked at 1850 to $1840 \mathrm{Ma}$ (Taylor and Kalsbeek, 1990; Kalsbeek and Nutman, 1996; Whitehouse and others, 


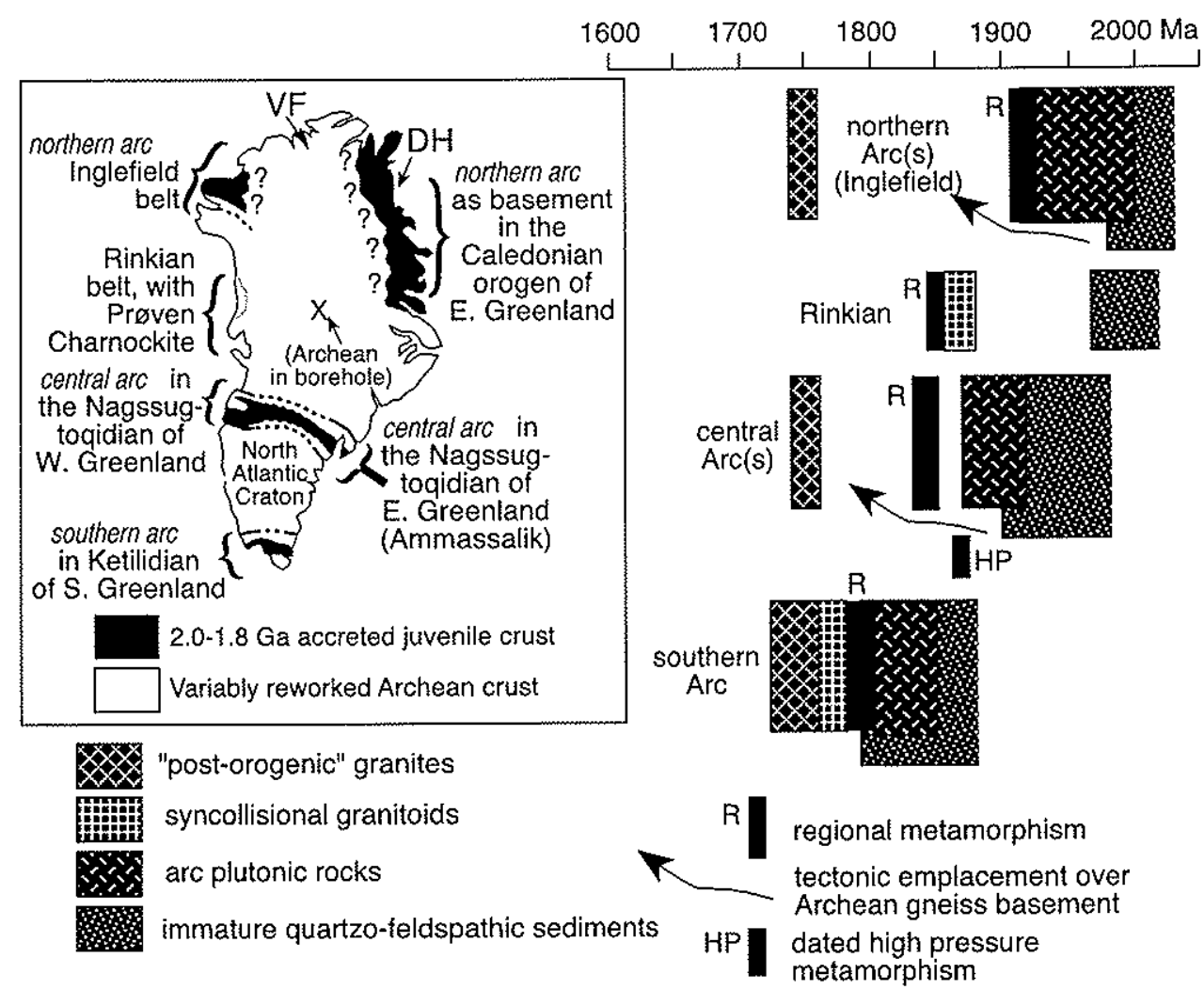

Fig. 13. Syuthesis of Paleoproterozoic crustal evolution of Greenhand. (A) Delineation of northem, central and southem jwenile arcs within Paleoproterozoic orogenic belts. (B) Ages for arc magmatism, youngest detrital zircons in arc-related rocks, metamonshism, post collisional granites, age of mafic dikes, and extensional basins. See text for explanation and key references.

1998; Nutman and others, 1999; Connelly and others, 2000). Ar-Ar studies show that this was followed by a long period of cooling (Willigers and others, 2001, 2002). Hence there are similarities between the chronology of arc magmatism and metamorphism in the eastern and western segments of the Nagssugtoqidian (fig. 13). This is compatible with geophysical evidence that they are the same orogenic belt (Verhoef and others, 1996).

\section{Assembly of Greenland from Paleoproterozoic Arcs and Archean 'Microcontinents'}

Kalsbeek (1981) proposed on the basis of $\mathrm{Rb}-\mathrm{Sr}$ whole rock data that Archean basement was widespread north of the Paleoproterozoic Nagssugtoqidian front along the northem edge of the North Atlantic Craton (fig. 13). The wide scatter about individual $\mathrm{Rb}-\mathrm{Sr}$ isochrons indicated that in many areas Archean basement gneisses had been affected by superimposed Paleoproterozoic ('Hudsonian') metamorphism. The most obvious exception was the Ketilidian orogen of South Greenland, which by then was already recognized to contain Paleoproterozoic plutonic rocks (for example, van Breemen and others, 1974).

In the 1980 s there was broader application of zircon and $\mathrm{Sm}-\mathrm{Nd}$ whole rock geochronology to basement complexes. In the Nagssugtoqidian orogenic belt in West Greenland, these methods identified tracts of Paleoproterozoic meta-granitoids and 
gneisses with radiogenic isotopic signatures showing that they are juvenile additions to the crust, and whose calc-alkaline geochemistry resembles that found in Phanerozoic arcs at convergent plate boundaries (Kalsbeek and others, 1987). These are embedded in 'reworked' Archean gneisses of the Nagssugtoqidian orogenic belt. From this data, Kalsbeek and others deduced that north of the Ketilidian orogen, the gneissose basement of Greenland (starting with the Nagssugtoqidian mobile belt), contains cryptic Paleoproterozoic sutures marked by rocks formed in Paleoproterozoic arcs.

By the 1990s with copious zircon U/Pb dating (particularly by SHRIMP), Nd isotopic analysis and further methodical mapping, a major tract of juvenile Paleoproterozoic crust was found to form much of the basement in the Caledonian orogen of North-East Greenland (Kalsbeek and others, 1993) and within the Inglefield mobile belt of Northern West Greenland (Dawes and others, 1987; Nutman and others, 2008). Correlation between these Paleoproterozoic domains in northern Greenland is uncertain, and it is possible that the two belts are entirely unrelated.

With the completion of a geochronological program in the Inglefield belt of North-West Greenland (Nutman and others, 2008) together with the result from the eastern sector of the Nagssugtogidian belt presented in this paper, it is possible to make the most complete synthesis yet of the evolution of the Greenland basement (fig. 13). This synthesis is an amalgamation of numerous geological and isotopic studies, for which only key references can be given here. This synthesis extends, and largely agrees with, the recent one by St-Onge and others (2006). Three tracts of Paleoproterozoic juvenile arc rocks have been recognized in Greenland, particularly on the basis of zircon dating and Nd isotopic studies (for example, Kalsbeek, 1986; Kalsbeek and others, 1993a, 1993b; Whitehouse and others, 1998; Garde and others, 2002 and references therein).

The northem arc tract (fig. 13) dominates the Inglefield mobile belt of North-West. Greenland. The extension of this arc underneath the Inland Ice to rocks of similar age and origin on the east coast is unconfirmed. The northern boundary of this arc is largely obscured by the Inland Ice and by Mesoproterozoic-Paleozoic platform sediments. However a window to the basement in Victoria Fjord (VF on fig. 13) contains Archean basement gneisses (Hansen and others, 1987; Numan and others, 2008) and Sm-Nd data on erratic granitic boulders derived from crystalline basement underneath the Inland Ice further east yield Archean $T_{\text {DM }}$ values (Kalsbeek and Frei, 2006). These occurrences indicate the presence of Archean basement in northernmost Greenland. The northern arc tract in North-West Greenland is bounded on its southern side by intercalations of quartzites, pelites and marbles with Archean gneisses that were metamorphosed and deformed in the Paleoproterozoic (Dawes and others, 1987; Nutman and others, 2008). Metamorphosed diabase dikes in the northernmost Archean basement contain garnet (largely decompressed to plagioclase and amphibole; Nutman, 1984) and in Archean metasediments, (Archean?) orthopyroxene is mantled by garnet corona structures (Garde and others, 1984). These might point to transient early' high pressures during Paleoproterozoic metamorphism.

In West Greenland between the northern and central arcs lies the Rinkian mobile belt (Henderson and Pulvertaft, 1987), in which Archean basement gneisses and overlying Palcoproterozoic metasediments (Kalsbeek and others, 1998 and references therein) were intensely folded into large-scale recumbent structures. Early high-grade metamorphism has been dated at $1881 \pm 20 \mathrm{Ma}$ (Taylor and Kalsbeek, 1990). Basement gneisses and their Paleoproterozoic cover were intruded by the $1869 \pm 9 \mathrm{Ma}$ Prøven Chanockite (fig. 13; Thrane and others, 2005, and references therein). The Prøven Charnockite is a large, orthopyroxene-bearing granite with geochemical affnity with $A$-type granites, rather than calc-alkaline juvenile arc suites (Thrane and others, 2005). Thrane and others interpreted the Prøven Charnockite to have formed 
in the passive margin side of a colliding pair of Archean cratons. It might form the edge of the massive Cumberland batholith of the same age to the west in Arctic Canada (fig. 13; Thrane and others, 2005).

The central are tract lies within the Nagssugtoqidian orogen (fig. 13). In both East and West Greenland, the Nagssugtoqidian mobile belt is bounded on its north side by domains of Archean crust that are devoid of penetrative Palacoproterozoic deformation and high grade metamorphism (for example, this paper). The belt contains a complex collage of (a) Paleoproterozoic magmatic rocks with arc-like geochemical signatures intruded in to immature quartzo-feldspathic sediments derived mostly from Palaeoproterozoic detritus (Kalsbeek and others, 1987; Nutman and others, 1999; Kalsbeek, 200I), (b) earliest Paleoproterozoic quartzites and marbles with abundant Archean detrital zircons and evidence of early high pressure metamorphism via kyanite and (c) Archean gneisses cut by variably, but generally strongly deformed Paleoproterozoic metadiabase dikes with vestiges of high pressure metamorphism (this paper and Nutman and others, 1999). The latter occur deep within the orogen, and in the northernmost autochthonous parts of the North Atlantic Craton (Nutman and others, 1999). Within the central part of the orogen, detailed mapping combined with zircon dating shows that a juvenile Palaeoproterozoic arc assemblage was thrust at least $50 \mathrm{~km}$ over Archean gneisses capped by marble-rich sediments that acted as the decollement (Kalsbeek and Nutman, 1996). A recent synthesis of the western segment of the orogen proposes two northerly-directed subduction zones, the southern of which gave rise to the Sisimiut chanockite complex where Nd isotopic data shows some contribution from Archean crust, and the northern one represented by the Arfersiorfik complex, with lesser contributions from Archean crust (St-Onge and others, 2006).

The southern are tract lies within the Palacoproterozoic Ketilidian orogen of southermmost Greenland. Detailed work in this orogen summarized by Garde and others (2002) demonstrates that it contains an Andean-style arc named the Julianehåb batholith, developed over a northerly-dipping oblique subduction zone at the southern edge of the North Atlantic Craton. A highly metamorphosed forearc sedimentary prism related to the Julianehåb batholith forms southernmost Greenland.

The Paleoproterozoic arcrelated rocks, the youngest ages of detrital zircons in associated immature volcanosedimentary sediments, regional metamorphism, dating of high pressure metamorphism, younger syncollisional granites and post-orogenic granite intrusions are assembled in figure 13. These reveal that throughout much of Greenland there is a southelly progression in the ages of Palaeoproterozoic crustal accretion and metamorphism. The Palaeoproterozoic arc rocks in the Caledonian basement of North-East Greenland are presently left out of this appraisal, because it is uncertain how they link with rocks of similar character to the west on the other side of the Inland Ice. The northern arc tract contains 1950 to $1920 \mathrm{Ma}$ juvenile crustal components, the youngest detrital zircons are circa $1980 \mathrm{Ma}$, and regional metamorphism occurred at circa 1920 Ma. Metamorphism in the arc assemblage was HT-LP (orthopyroxene grade). The central arc tract (in the Nagssugtoqidian), contains 1920 to $1870 \mathrm{Ma}$ arc rocks. The detrital zircons in immature metasediments associated with the arc rocks are overwhelmingly Palaeoproterozoic, with the youngest being circa $1900 \mathrm{Ma}$ old (Nutman and others, 1999). In the East Grcenland segment of this orogen, high pressure metamorphism up to eclogite facies in underlying basement rocks has been documented at circa $1870 \mathrm{Ma}$ (this paper) coeval with the youngestdated intrusions (Connelly and others, 2000) from the arc assemblages in West Greenland. This probably marks the end of arc magmatism with the collision of northern and southern continental masses, crustal thickening and transient high pressure metamorphism at depth. All rocks of the central orogen show high-grade 
metamorphism at 1850 to $1840 \mathrm{Ma}$ (for example, Taylor and Kalsbeek, 1990; Nutman and others, 1999; Connelly and others, 2000; this paper), coeval with folding and local anatexis during crustal equilibration. In the southern arc Julianehåb batholith in the Ketilidian orogen) the onset of arc magmatism at the southern margin of the North Atlantic Craton was at circa $1840 \mathrm{Ma}$ and lasted until circa $1790 \mathrm{Ma}$ (Garde and others, 2002 , and references therein). The youngest detrital zircons associated with the Julianehåb batholith are circa $1790 \mathrm{Ma}$. This was succeeded between 1790 to $1740 \mathrm{Ma}$ by metamorphism and the intrusion of S-type granites formed by melting of the forearc sedimentary prism and by rapakivi granites in the southernmost part of the orogen.

Thus during the Palaeoproterozoic (2000-1790 Ma), Greenland basement was created by the growth of arc complexes and their collision and amalgamation with 2000 to $1000 \mathrm{~km}$ wide Archean basement gneiss massifs ('microcontinents') fringed by Palaeoproterozoic passive margin sequences (clean quartzites, carbonates and pelites). For the southern arc it is well established that subduction was northwards towards the North Atantic Craton, and that it entailed a degree of oblique movement. We suggest in this paper that subduction related to the Ammassalik region eastern section of the central arc tract was also northwards, such that upon collision, the arc assemblage overrode the edge of the North Atlantic Craton (in which transient high pressure metamorphism took place; fig. 13). This is in accord with suggested polarity for probably 2 subduction zones within the western section of the Nagssugtoqidian (for example, St-Onge and others, 2006). The presence of local Palaeoproterozoic high pressure granulite assemblages at the northern edge of the North Atlantic Craton would fit with northerly-directed subduction. For the northern arc, northwards subduction is inferred by Nutman and others (2008).

Across Greenland, latest Palaeoproterozoic events between 1775 and $1680 \mathrm{Ma}$ were intrusion of A-type granites including rapikivi granites in the Ketilidian orogenic belt and transcurrent shearing. Although much of this activity is found within the Palacoproterozoic mobile belts, Rb-Sr mineral ages demonstrate general heating and locally intrusion of granite dikes in the Archean domains (Kalsbeek and others, 1980; Baadsgaard and others, 1986). Unlike the timing of Palaeoproterozic arc magmatism and regional metamorphism, there are no changes in ages across Greenland for this activity (fig. 13). These pan-Greenland thermal event(s) might indicate the start of extension and high heat flow leading to continental break-up in the Mesoproterozoic.

\section{CONCLUSIONS}

- The zircon dating presented here confirms the finding of Hansen and Kalsbeek (1989) and Kalsbeek and others (1993) that the Ammassalik Intrusive Complex and Paleoproterozoic meta-tonalites in the eastern Nagssugtoqidian orogen are early (pre-collisional) intrusions assumedly belonging to arc suites. They are not, as suggested by Bridgwater and Myers (1979) and Friend and Nutman (1989), late tectonic intrusions. Their ages overlap with those for arc rocks in Nagssugtoqidian orogen in West Greenland (Kalsbeek and Nutman, 1996; Whitehouse and others, 1998; Connelly and others, 2000). The moderate pressure granulite facies metamorphism dated here at $1905 \pm 49 \mathrm{Ma}$ (within its large uncertainty) is interpreted to have been coeval with the emplacement of these arc rocks.

- Metadiabase dikes cutting Archean basement gneisses strongly deformed in Paleoproterozoic orogeny have a minimum zircon age of $2015 \pm 15 \mathrm{Ma}$, close in age to the Kangâmiut dikes cutting the southern foreland of the Nagssugtoqidian orogen in West Greenland (Nutman and others, 1999).

- Eclogite facies metamorphism locally preserved in the circa 2015 Ma metadiabase dikes is shown by a combination of $\mathrm{U} / \mathrm{Pb}$ dating and trace element analysis of zircons to have occurred at $1867 \pm 28 \mathrm{Ma}$, close on the time of cessation of arc 
magmatism. This records the timing of maximum pressure (>11 kbar) at high temperature (circa $750^{\circ} \mathrm{C}$ ) following crustal thickening in a collisional orogeny.

- Zircon growth and recrystallization at 1870 to $1840 \mathrm{Ma}$ is also recorded in several samples. This probably reflects further high grade metamorphism, as unrelated groups of rocks were folded together following the collisional stage of orogeny. Exactly the same age for regional metamorphism is recorded in the West Greenland part of the Nagssugtoqidian orogeny (Taylor and Kalsbeek, 1990; Nutman and others, 1999; Connelly and others, 2000).

- Archean gneisses in the northern part of the Nagssugtoqidian orogen of East Greenland have yielded zircon $\mathrm{U} / \mathrm{Pb}$ protolith ages varying from 3035 to $2734 \mathrm{Ma}$. Metamorphic zircon rims in these samples gave ages around $2720 \mathrm{Ma}$; and no evidence was found of Paleoproterozoic zircon growth. This is a useful indicator of the northern limit of this orogen in East Greenland.

- There is a close parallel between ages of rock units and metamorphic events in the Nagssugtogidian of West and East Greenland. Taken together, the orogen is a result of a Paleoproterozoic collisional orogeny (Kalsbeek and others, 1987 onwards), whereby 1920 to $1870 \mathrm{Ma}$ arcs were juxtaposed with blocks of Archean continental crust (see also St-Onge and others, 2006). Archean blocks (with Paleoproterozoic cover sequences) that were deeply buried in the collision underwent transient highpressure metamorphism, given here by the date of $1867 \pm 28 \mathrm{Ma}$ for eclogite facies metamorphism.

- Previously published results combined with those presented here and from the Inglefield mobile belt of North-West Greenland (Numan and others, 2008), suggest that in the Paleoproterozoic, Greenland basement was formed by amalgamation of arc complexes with intervening blocks of Archean gneisses [northern arc(s) 2000-1940 Ma with collision at $1940 \mathrm{Ma}$; central arc(s) $1920-1870 \mathrm{Ma}$ with collision at $1870 \mathrm{Ma}$; southern arc 1850-1790 Ma with metamorphism at $1790 \mathrm{Ma}$ ]. This can be likened to in the Mesozoic, with the ongoing transfer of continental fragments from Gondwana onto the margin of Eurasia, also with the development of several arc complexes. This is compelling evidence for the assembly of Greenland by plate tectonic processes in the Paleoproterozoic.

ACKNOWLLDGMI:NTS

The six digit sample numbers, in official archives with the prefix ' $G G U$ ', refer to material in the files of the Geological Survey of Denmark and Greenland (GEUS), Copenhagen. We are grateful to Peter Venslev, University of Copenhagen, Geocenter Copenhagen, for separating the zircons used in the SHRIMP analysis. The paper is published with the permission of the Geological Survey of Denmark and Greenland. Thorough and constructive reviews by Kenneth McCaffrey and Adam Garde greatly improved the manuscript.

\section{RHYH:NCIS}

Baadsgaard, H., Nutman, A. P., Rosing, M. T., Bridgwater, D., and Longstaffe, F. J., 1986, Asteration and metamorphism of the Amitsoq gneisses from the Isukasia area, West Greenland: Recommendations for isolope studies of the early crust: Geochimica et Cosmochimica Acta, v. 50, p. 2165-2172.

Bridgwater, D., and Myers, I. S., 1979, Outline of the Nagssugtoqidian molble belt of East Greenland: Rapport Gronlands geologiske Undersøgelse, v. 89, p. 9-18.

Chadwick, B., and Vasudev, V. N., 1989, Some observations on the structure of the early Proterozoic, Ammassalik mobile belt in the Ammassalik region, Soutl-East Greenland: Rapport Grønlands geologiske Undersøgelse, v. 146, p. 29-40.

Chadwick, B., Dawes, P. R., Escher, J. C., Friend, C. R. L., Hall, R. P., Kalsbeek, T. F. D., Nutman, A. P., Soper, N. J, and Vasudev, V. N., 1989, The Proterozoic mobile belt in the Ammassalik region, South-1 East Greenland (Ammassalik mobile belt): an introduction and re-appraisal: Rapport Gronlands geologiske Undersøgelse, v. 146, p. 5-12. 
Connelly, J. N, van Gool, J. A. M., and Mengel, F. C., 2000, Temporal evolution of a deeply eroded orogen: the Nagssugtogidian orogen, West Greenland: Canadian Journal of Earth Sciences, v. 37, p. 1121-1142.

Dawes, P. R., Larsen, O., and Kalsbeek, F., 1987, Archean and Proterozoic crust in North-West Greenland: evidence from Rb-Si whole-rock age decerminations: Canadian Joumal of Kiarth Sciences, v. 25, p. 1365-1373.

Dawes, P. R., Friend, C. R. L., Numan, A. P., and Soper, N. J., 1989a, The Blokken gneisses: a re-appraisal: Rapport Grssnlands geologiske Undersøgelse, $v .146$, p. 83-86.

Dawes, P. R., Soper, N. J., Escher, J. C., and Hall, R. P., 1989t, The nortles boundary of the Proterozoic (Nagssugtoqidian) mobile belt of Soutl-East Greenland: Rapplost Grønlands geologiske Undersøgelse, v. $146,13.54-65$.

Eggins, S. M., Rudnick, R. L.., and McDonough, W. F., 1998, The composition of peridotites and their minerals: a laser ablation ICP-MS study: Earth and Plametary Science Letters, v. I54, v. 53-71.

England, P., and Thompson, A. B., 1984, Pressute-temperature-time paths of regional metamonolism, 1 , Heat transfer during evolution of regions of thickened continental crust: Joumal of Petrology, v. 25, p. $894-928$.

Escher, J. C. (compiler), 1990, Geological map of Greenland 1:500 000, sheet 14, Skjoldungen: Copenhagen, Geological Survey of Greenland.

Escher, J. C., and Hall, R. P., 1989, The Niflheim thrust: a tectonic contact between granulite and amphibolite facies gneisses, Sonth-East Greenland: Rapport Grønlands geologiske Undersøgelse, v. 146, p. $66-69$.

Escher, J. C., Friend, C. R. L., and Hall, R. P., 1989, The southem boundary zone of the Proterozoic mobile belt, Soutb-East Greenland: geology of the area between Gyldenlsve Fjord and Isertog: Rapport Grsulands geologiske Undersogelse, v. 146, p. 70-78.

Friend, C. R. L., and Numan, A. P., 1989, The geology and structural setting of the Proterozoic Ammassalik Intrusive Complex, East Greenland: Rapport Gronlands geologiske Undersøgelse, v. 146, p. 41-45.

Garde, A. A., Glassley, R., and Nutman, A. P., 1984, Two-stage corona growth during Precambrian granulite facies metamorphism of Smi hson Bjerge, northwest Greenlausd: Goumal of Metamorphic Geology, v. 2, p. $237-247$.

Garde, A. A., Hamilton, M. A., Chadwick, 13., Grocott, J., and McCaffrey, K. I. W., 2002, The Ketalidian orogen of Soutly Greenland: geochronology, tectonics, magmatism, and fore-arc accretion during Palacoproterozoic oblique convergence: Canadian Journal of Earth Sciences, v. 39, p. 765-793.

Hall, R. P., Chadwick, B., Escher, J. C., and Vasudev, V. N., 1989, Supracrustal rocks in the Ammassalik region, South-East Greenland: Rajport Gronlands geologiske Undersøgelse, v. 146, p. 17-22.

Hansen, B. T., and Kalsibee, F., 1989, Precise age for the Ammassatik Intrusive Complex; Rapport Groniands geologiske Undersøgelse, v. 146, p. 46-47.

Hansen, B. T., Kalsbeek, F., and Holm, P. M., 1987, Archacan age and Proterozoic metamorphic overprinting of the cyystalline basement at Victoria lijord, North Greenland: Rapport Gronlands Geologiske Undersøgelse, v. 133, p. 159-168.

Henderson, G., and Pukertaft, T. C. R., 1987, Geological map of Greenland, 1:100 000, Mâmorilik 71 V.2 Syd, Núgâtsiaq 71 V.2 Nord, Pagnertôg 72 V.2 Syd: Copenlıagen, Geological Survey of Greenland, Descriptive text, 72 p.

Hermam, J., Rubatto, D., Korsakov, A., and Shatsky, V. S., 2001, Multiple zircon growth during fast exhumation of diamondiferous, deeply subducted continental crust (Kokchetav Massif, Kazaklsstan): Contributions to Mineralogy and Petrology, v. 14.1, p. 66-82.

Kaisbeek, F., 1981, The northward extent of the Archaean basement of Greenland - a review of $\mathrm{Rb}-\mathrm{Sr}$. whole-rock ages: Precambrian Research, v. 14, p. 203-219.

— 1986, The tectonic framework of the Precambrian shield of Greenland. A review of new isotopic evidence: Rapport Gronlands geologiske Underschelse, v. 128, p. 55-64.

- (editor), 1989, Geology of the Ammassalik region, Soutli-East Greenland: Rappon Gronlands geologiske Undersogelse, v. 146, p. 1-112.

2001, Geochemical comparison between Archaean and Palaeoproterozoic orthogneisses from the Nagssugtogidian orogen, West Greenland: Precambrian Research, v. 105, p. 165-181.

Kalsbeek, F., and lirei, R, 2006, The Mesoproterozoic Midsommerso dolerites and associated high-silica intrusions, North Greenland; crustal melting, contamination and hydrothermal alteration: Contributions to Mineralogy and Petrology, v. 152, p. 89-110.

Kalsbeek, $Y$, and Manatschal, $G$., 1999, Geochemistry and tectonic significance of peridotitic and metakomatiitic rocks from the Ussuit area, Nagssugtoqidian orogen, West Greenland: Precambrian Research, v. 94, p. 101-120.

Kalsbeek, F., and Nielsen, T. F. D., 1987, Regional geological investigations in the Ammassalik district, South-East Greenland: Rapport Grønlands geologiske Undersøgelse, v. 135, p. $59 m 66$.

Kalsbeek, F., and Nutman, A. P., 1996, Anatomy of the easly Proterozoic Nagssugtogidian orogen, West Greenland, explored by recomatissance SHRIMP U-Pb zircon dating: Geology, v. 24, p. 515-518.

Kalsiseek, F., and Taylor, P. N., 1989, Programme of geochronology and isotope chemistry in the Ammassalik region, Soutly-East Greenland: outline and preliminary restilts: Rappont Grønlands geologiske Unders $\phi$ gelse, v. 146, p. 13-16.

Kalsbeek, F., Bridgwatcr, D., and Boak, J., 1980, Evidence of mid-Proterozoic granite formation in the Isua area: Rapport Grønlands geologiske Underssgelse, v. 100, p. 73-75.

Kalsbeek, F., Pidgeon, R. T., and Taylor, P. N., 1987, Nagssugtoqidian mobile belt of West Greenland: a cryptic 1850 Ma sutire between iwo Archaean continents - chemical and isotopic evidence: Earth and Planetary Sciences Letters, v. 85, p. 365-385. 
Kalsbeek, F., Austrheim, H., Bridgwater, D., Hansen, B. T., Pedersen, S., and Taylor, P. N., 1993a, Geochnonology of Archaean and Proterozoic events in the Ammassalik area, South-Last Greenfand, and comparisons with the Lewisian of Scotland and the Nagssugtogidian of West Greentand: Precambrian Research, v. 62, p. $239-270$.

Kalsbeek, F., Nutman, A. P., and Taylor, P. N., 1993b, Palaeoproterozoic basement province in the Caledonian fold belt of North-Last Greenland: Precambrian Researcl, v, 63, p. 163-178.

Kalsieek, F., Pulvertaft, 'T. C. R., and Nutman, A. P, 1998, Geochemistry, age and origin of metagreywackes from the Palacoproterozoic Kanat Group, Rinkian Belt, West Greenland: Precambrian Research, v. 91 , p. 383-399.

Lee, J. K. W. Williams, I. S., and Ellis, D. J., 1997, Pb, U and Th diffusion in natural zircon: Nature, v, 390 , p. $159-162$.

Liati, A., Froitzhem, N., and Fanning, C. M., 2005, Juassic ophiolites within the Valais domain of the Westem and Central Alps: Geochronological evidence for re-rifting of oceanic crust: Contributions to Mineralogy and Petrology, v, 149, p. 446-461.

Ludwig, K., 1997, Isoplot/ Ex: Berkeley, Califomia, Berkeley Geochronology Center, Publication 1.

Manatschal, G., Ulfbeck, D., and van Gool, y., 1998, Change from thrusting to syncollisional extension at a mid-crustal level: an example from the Palaeoproterozoic Nagssigtoqidian Orogen (West Greenland): Canadian Goumal of Earth Sciences, v. 35, p. 802-819.

Markl, G., and Bucher, K., 1997, Proterozoic eclogites from the Lofoten islands, northern Norway: Lithos, v. 42, p. $15-35$.

Mengel, F. C., Bridgwater, D., Atstrhein, H., Hansen, B. T., Winter, J., and Pedersen, S., 1990, The metamorphic history of the Nagssugtoqidian mobile belt, East Greenland: Geoliska Föreningens $\mathrm{i}$ Stockholm Förthandingar, v. 112 , p. $298-299$.

Miyashiro, A., 1973, Paired and unpaired metamorphic belis: Tectonophysics, v. 17, p. 241-254.

Myers, ]. S., 1987, The East Greenland Nagssugtogidian mobile belt compared with the Lewisian complex, in Park, R. G., and 'armey, J., editors, Evolution of the Lewisian and Comparable Precambrian High Grade. Terrains: London, Geological Society Special Publication, v. 27, p. 235-246.

Noman, M. D., Pearson, N.J., Sharma, A., and Griffin, W. L., 1996, Quantitative analysis of trace edements in geological materials by laser ablation ICPMS: instrumental operating conditions and calibration values for NIST glasses: Geostandards Newsleter, v. 20, p. 247-261.

Nutman, A. P., 1984, Precambrian gneisses and intrusive anorthosite of Smithson Bjerge, Thule district, North-West Greenland: Rapport Gronlands Geologiske Undersøgelse, v, 119, 31 p.

Nutman, A. P., and Friend, C. R. L., 1989, Recomnassance P, T studies of Proterozoic crustal evolution of the Ammassalik area, East Greenland: Rappont Gronlands geologiske Undersøgelse, v. 146, p. 48-53.

Nutman, A. P., Chernyshev, I. V., Baadsgaard, H., and Smelov, A. P., 1992, The Aldan Sheld of Siberia, U.S.S.R.: The age of its Archaean components and evidence for widespread reworking in the Mid Proterozoic: Precambrian Research, v. 54, j. 195-210.

Nutman, A. P., Kalsbeek, K., Marker, M., van Cool, J. A. M., and Bridgwater, D., 1999, U-Pl, zircon ages of Kangâmiut dykes and detrital zircons in metasediments in the Palaeoproterozoic Nagssugtoqidian Orogen (West Greenland): Clues to the pre-collisional history of the orogen: Precambrian Rescarch, v. 93, p. $87-104$.

Nutman, A. P., Dawes, P. R. D., Kalsbeek, F, and Hamiłton, M. A., 2008, Palaeoproterozoic and Archaean gneiss complexes in northem Greenland: Palaeoproterozoic terane assembly in the High Arctic: Precambrian Reseatch, v. 161, p. 419-451.

O'Brien, P. ., and Rötzler, J., 2003, High+pressure granulites: fomation, recovery of peak conditions and implications for tectonics: foumal of Metanorphic Petrology, v. 21, p. 3-20.

Poldervart, A., 1956, Zircon in rocks. 2. Igneous rocks; American Journal of Science, v. 254, p. $521-554$.

Rubato, D., 2002, Zircon trace element geochemistry: partitioning with garnet and the link between U-Pb ages and metamorphism: Chemical Geolog;, v. 184, p, 123-138.

Rubatto, D., and Hemann, J., 2001, lexhmation as fast as subduction?: Geology, v. 29, p. 3-6.

Rubato, D., and Scambellusi, M., 2003, U-Pb dating of magmatic zircon and metamorphic baddeleyite in the Ligurian eclogites (Volui Massif, Westem Alps): Contributions to Mineralogy and Petrology, v, 146 , p. $341-355$.

Rubatio, D., Gebaner, D., and Ganning, M., 1998, Jusassic formation and Locene subduction of the ZermattSaas-Fee ophiolites: Implications for the geodynamic evolution of the Central and Westem Algs: Contributions to Mineralogy and Petrology, v. 132, p. 269-287.

Smelov, A. P., and Beryozkin, V. I., 1993, Retrograded eclogites in the Olekma granite-greenstone region, Aldan Shield, Siberia: Precambrian Research, v, 62, p. 419-430.

Stem, R. A., 1998, High-mesohtion SIMS determination of radiogenic tace-isotope ratios in minerals, in Cabri, L. J., and Vaughan, D. J., editors, Modern approaches to ore and envirommenal mineralogy: Mineralogical Association of Canada Short Course Series, v. 27, p. 241-268.

St-Onge, M., (compiler) with contributions from Van Gool, J. A. M., Garde, A. A., and Scot, D. J., 2006, Correlation of Archaean to Mesoproterozoic units and structures across Baffin Bay, Davis Strait, and the Labuador Sea: Kangerhussuaq workshop 2005 report and literature review, in Stendal, H, and Stensgaasd, B. M., editors, Geology and mineral resources in Greenland and northeastern North America: Danmarks og Gronlands Geologiske Undersagelse, Rapport v. 2006/6, p. 21-57.

Taylor, P. N., and Kalsbeek, F., 1990, Dating the metamorphism of Precambrian marbles: Examples from Proterozoic mobile belts in Greenland: Clremical Geology, v. 86, p. 21-28.

Thrame, K., Baker, J., Connelly, J., and Nutman, A., 2005, Age petrogenesis and metamorphism of the syo-collisional Prøven Igneous Complex, West Greenland: Contributions to Mineralogy and Petrology, v. $149, p, 541-555$. 
van Bremen, O., Aftalion, M., and Albart, ]. H., 1974, Isotopic and geochromologic studies on granites fiom the Ketilidian mobite belt of South Greenland: Geological Society of America Bulletin, v, 85, 3), 403412.

van Gool, J. A. M., Connelly, J. N., Marker, M., and Mengel, F. C., 2002, The Nagssugtoqiclian orogen of West Geenland: tectonic evolution and regional correlations from a West Greenland perspective: Canadian Joumal of Eartl Sciences, v. 39 , p. $665-686$.

Verboef, I. Macmab, R., Roest, W., and Arjani-Hamed, J., 1996, Magnetic anomalies of tlse Arctic and North Alanic oceans and adjacent land areas. GAMMAAS (Gridded Aeromagnetic and Marine Magnetics of the north Atlantic and Arctic, $5 \mathrm{~km}$ ): Geological Survey of Canada, Open lile Report $3125 a$.

Whitehouse, M.J., Kalsbeek, F., and Nutman, A. P., 1998, Crustal growth and crustal recycling in the Nagssugtogidian orogen of West Greenland: Constaints from radiogenic isotope systematics and U-Pb zircon geochronology: Precambrian Research, v. 91, p. 365-381.

Williams, I. S., 1998 , U-Th-Pb geochmonology by ion microprobe, in Applications of microanalytical techniques to understanding minemalizing processes, in McKibben, M. A., Shanks, W.C.P., III., and Ridley, W. I., editors: Society of Economic Geologists Shom Course, v. 7.

Willigers, B. J. A., Krogstad, E. J., and Wijbrans, J. R., 2001, Comparison of themochronometers in a slowly cooled granulite terrain: Nagssugtogidian Onogen, West Greenland: Joumal of Petrology, v. 42, p. $1729-1749$.

Willigers, B. J. A., van Cool, J. A. M., Wijbrans, J. R., Krogstad, E. J., and Mezger, K., 2002, Post-iectonic cooling of the Nagssugtoqidian Orogen and a comparison of contrasting cooling histories in Precambrian and Phanerozoic orogens: Journal of Ceology, v. 110, p. 503-517.

Wright, A. E., Tamey, J., Palmer, K. F., Moorlock, B. S. P., and Skinner, A. C., 1973, The geology of the Angmagssalik area, East Greenland and possible relationships with the Lewisian of Scolland, in Park, R. G., and Tarney, ], editors, The early Precambrian of Scotand and related rocks in Greenland: United Kingdom, University of Keele, p. 157-177.

Zhao, G., Cawood, P. A., Wilde, S. A., Sun, M., and Lu, L., 2000, Metamorphism of basement rocks in the Cental Zone of the North China Craton: implications for Paleoproterozoic tectonic evolution: Precambrian Research, v. 103, p. 55-88. 